\title{
Physiological Effects of Neonicotinoid Insecticides on Non-Target Aquatic Animals-An Updated Review
}

\author{
Nemi Malhotra ${ }^{1,+}$, Kelvin H.-C. Chen ${ }^{2,+}{ }^{\oplus}$, Jong-Chin Huang ${ }^{2}{ }^{\oplus}$, Hong-Thih Lai ${ }^{3}{ }^{\oplus}$, Boontida Uapipatanakul ${ }^{4}(\mathbb{D}$, \\ Marri Jmelou M. Roldan ${ }^{5}$ (D), Allan Patrick G. Macabeo ${ }^{6, *(\mathbb{D})}$, Tzong-Rong Ger 1,7,8,*(D) \\ and Chung-Der Hsiao $7,8,9,10, *$ (D)
}

Citation: Malhotra, N.; Chen, K.H.-C.; Huang, J.-C.; Lai, H.-T.; Uapipatanakul, B.; Roldan, M.J.M.; Macabeo, A.P.G.; Ger, T.-R.; Hsiao, C.-D. Physiological Effects of Neonicotinoid Insecticides on Non-Target Aquatic Animals-An Updated Review. Int. J. Mol. Sci. 2021 22, 9591. https://doi.org/10.3390/ ijms22179591

Academic Editor: Steeve Hervé Thany

Received: 29 June 2021

Accepted: 2 September 2021

Published: 4 September 2021

Publisher's Note: MDPI stays neutral with regard to jurisdictional claims in published maps and institutional affiliations.

Copyright: (c) 2021 by the authors. Licensee MDPI, Basel, Switzerland. This article is an open access article distributed under the terms and conditions of the Creative Commons Attribution (CC BY) license (https:/ / creativecommons.org/licenses/by/ $4.0 /)$.
1 Department of Biomedical Engineering, Chung Yuan Christian University, Chung-Li 320314, Taiwan; nemi.malhotra@gmail.com

2 Department of Applied Chemistry, National Pingtung University, Pingtung 900391, Taiwan; kelvin@mail.nptu.edu.tw (K.H.-C.C.); hjc@mail.nptu.edu.tw (J.-C.H.)

3 Department of Aquatic Biosciences, National Chiayi University, 300 University Rd., Chiayi 60004, Taiwan; hongthih@gmail.com

4 Department of Chemistry, Faculty of Science and Technology, Rajamangala University of Technology, Thanyaburi 12110, Thailand; boontida_u@rmutt.ac.th

5 Faculty of Pharmacy, The Graduate School, University of Santo Tomas, Espana Blvd., Manila 1015, Philippines; mmroldan@ust.edu.ph

6 Laboratory for Organic Reactivity, Discovery and Synthesis (LORDS), Research Center for the Natural and Applied Sciences, University of Santo Tomas, Espana Blvd., Manila 1015, Philippines

7 Center for Nanotechnology, Chung Yuan Christian University, Chung-Li 320314, Taiwan

8 Research Center for Aquatic Toxicology and Pharmacology, Chung Yuan Christian University, Chung-Li 320314, Taiwan

9 Department of Chemistry, Chung Yuan Christian University, Chung-Li 320314, Taiwan

10 Department of Bioscience Technology, Chung Yuan Christian University, Chung-Li 320314, Taiwan

* Correspondence: agmacabeo@ust.edu.ph (A.P.G.M.); sunbow@cycu.edu.tw (T.-R.G.); cdhsiao@cycu.edu.tw (C.-D.H.)

+ Co-first authors.

Abstract: In this paper, we review the effects of large-scale neonicotinoid contaminations in the aquatic environment on non-target aquatic invertebrate and vertebrate species. These aquatic species are the fauna widely exposed to environmental changes and chemical accumulation in bodies of water. Neonicotinoids are insecticides that target the nicotinic type acetylcholine receptors (nAChRs) in the central nervous systems (CNS) and are considered selective neurotoxins for insects. However, studies on their physiologic impacts and interactions with non-target species are limited. In researches dedicated to exploring physiologic and toxic outcomes of neonicotinoids, studies relating to the effects on vertebrate species represent a minority case compared to invertebrate species. For aquatic species, the known effects of neonicotinoids are described in the level of organismal, behavioral, genetic and physiologic toxicities. Toxicological studies were reported based on the environment of bodies of water, temperature, salinity and several other factors. There exists a knowledge gap on the relationship between toxicity outcomes to regulatory risk valuation. It has been a general observation among studies that neonicotinoid insecticides demonstrate significant toxicity to an extensive variety of invertebrates. Comprehensive analysis of data points to a generalization that field-realistic and laboratory exposures could result in different or non-comparable results in some cases. Aquatic invertebrates perform important roles in balancing a healthy ecosystem, thus rapid screening strategies are necessary to verify physiologic and toxicological impacts. So far, much of the studies describing field tests on non-target species are inadequate and in many cases, obsolete. Considering the current literature, this review addresses important information gaps relating to the impacts of neonicotinoids on the environment and spring forward policies, avoiding adverse biological and ecological effects on a range of non-target aquatic species which might further impair the whole of the aquatic ecological web. 
Keywords: neonicotinoid; aquatic animal; toxicity; non-target species

\section{Neonicotinoids-An Overview}

Pesticides are chemical materials primarily used to prevent, control, destroy, repel or alleviate pests, protect crops and avoid vector-borne diseases [1,2]. They are further classified according to the particular type of pest. The molecular targets of pesticides are shared by non-target species, leading to potential unusual effects. Specific categorization includes herbicides, fungicides and insecticides [2-5]. In general, they are commercialized as pyrethroids, organophosphates and carbamates [6]. Neonicotinoids were discovered and developed in the 1980s and presented to the pesticide market and agricultural fields in the 1990s. Examples of commercially available neonicotinoids are imidacloprid, acetamiprid, thiacloprid and thiamethoxam with imidacloprid being the oldest to be approved. They have shown immense benefits in agriculture, forestry, industries, domestic landscape and public health contributing to economy [2,7]. However, current evidence shows that insecticides have potential risks associated with wild bees, honey bees, aquatic invertebrates, non-target insects and humans [2,8-11]. Many studies were reported showcasing the adverse effect of neonicotinoids on non-target organisms in the last decade $[1,2,12-16]$.

Illustrative uses of neonicotinoids in agriculture among crops such as maize, cotton, oil seed-rape, sunflower and sugarcane were demonstrated due to excellent solubility, chemical properties and selective control that assure diffusion in plants via xylem and phloem transport mechanisms [17]. The reason for their extreme movability in the soil leads to contamination of surrounding water bodies, which in turn impacts the areas on which they are applied. In effect, high water solubility, persistence and leaching potential neonicotinoids lead to transportation onto surface waters thus becoming toxic to aquatic life $[18,19]$. Pesticides can reach surface water through different routes, such as sprayers, surface run-off, seepage and atmospheric deposition of contaminated groundwater. Aquatic animals are an extremely important component of the aquatic ecosystem as they play the role of being sediment feeders, grazers, decomposers, parasites, and predators thus maintaining a balanced ecosystem [20]. The rising amounts of neonicotinoids in the environment raise concerns about their uptake through respiration, feeding, and onto the epidermis of the skin. In comparison to other insecticides, neonicotinoids are found in larger concentrations in freshwater systems [20,21]. The persistence and high toxicity effect may surge to a higher trophic level by changing food web structures and dynamics thus, distressing consumers on the higher levels. Over the last few decades, neonicotinoids have gained importance and are among the rapidly expanding major chemical classes of insecticides in the international marketplace [22-24]. When used as protection for plants, neonicotinoids are distributed systematically throughout growing plant following seed or soil applications that is why it is also known as systemic insecticides [25].

Aquatic organisms are relevant platforms to analyze and understand the toxicity of chemical compounds. Once aquatic animals are exposed to environmental pollutants at primary junctures, they respond very quickly. Many aquatic model species (both invertebrates and vertebrates) have been used to bridge the knowledge gap in consideration for studies of other vertebrates. Therefore assessment of toxicity of neonicotinoids to aquatic species will not only provide toxicity information but also, will shed light on the path of their potential impacts on other classes of vertebrates and human health in the long run [26]. It was observed that species under the same genus or family might exhibit different results when exposed to a similar chemical compound but variation in several factors such as time, dose, concentration, age of the organism, temperature, $\mathrm{pH}$, salinity, etc., play an important role in generating a convincing result [27]. Recently, attention was turned on investigating possible reasons for indirect effects such as effect to non-target aquatic organisms when applied to crops which might get mediated through amount, quality and concentration of the product used [25]. In this review, we evaluated the literature studies during the 
last decade (2010-2021) and discussed the potential adverse effects of neonicotinoids over non-target organisms to understand the safe limits on the use of neonicotinoids and their toxicity to understand their destructive persistent effects on an organism's behavior, health, genetic make-up, and other innate physiological properties. Herein, studies related to neonicotinoids toxicity on these non-target aquatic species are described and elaborated.

\section{Chemical and Physical Properties of Neonicotinoids}

Neonicotinoids are organic insecticides possessing acyclic and cyclic structures exhibiting differences in molecular properties [28]. The ring structure of neonicotinoids consists of different segments that comprise bridging fragments, a heterocyclic group, bridging tethers and functional groups. The methylene group is commonly used as a bridging chain. Either a methylene or ethylene substituent was found to decrease biological activity. The term neonicotinoid was suggested for imidacloprid and associated insecticidal compounds with a structure similar to the insecticidal alkaloid (S)-nicotine, exhibiting a similar mode of action [29-31].

Neonicotinoids are highly water-soluble compounds, relatively stable in buffers, water or other physiological media with $\mathrm{pH}$ 5-7. These compounds break down in the environment and are taken up by plants to provide resistance against insects. It was observed that stability of neonicotinoids decreases by increasing and/or decreasing $\mathrm{pH}$, e.g., $\mathrm{t}_{1 / 2}$ thiamethoxam at $\mathrm{pH}$ 5-7 degrades $>1$ year, however, it survives only a few days at $\mathrm{pH} 9$ [32]. Moreover, less photostability is noted for neonicotinoids possessing a nitromethylene group since its functionality absorbs strong sunlight in the range of 290-400 nm. For example, under direct sunlight, degradation of nithiazine takes place in minutes. Substitution of the nitromethylene group with less or no sunlight absorbing groups, e.g., nitromine in imidacloprid or cyanomine in acetamiprid, improves nicotinoid photo-stability significantly [33].

\section{Interaction and Selectivity Mechanisms of Neonicotinoid Insecticides}

Compared to nicotine, neonicotinoid insecticides are generally agonists of the nicotinic receptor that selectively interact with the nicotinic acetylcholine receptor (nAChR) of insects versus mammals. They are categorized as $\mathrm{nAChR}$ competitive modulators by the IRAC (Insecticide Resistance Action Committee) [34]. Thus, insecticidal properties of neonicotinoids can be attributed to their agonistic action on insect $n A C h R$ receptors which are biological receptors and classified under the cys-loop superfamily of ligand gated-ion channels [35]. They portray a critical function in fast cholinergic neurotransmission in vertebrate and invertebrate organisms [36]. The biochemical structure of nAChRs features an ensemble of four transmembrane domains, extracellular $N$-terminal interacting with ligands, and central cation channel with a cascade constructed by transmembrane domain 2 [37]. Depending on the structures of ligands and nAChR subtypes, neonicotinoids confer variegated effects, such as partial to superagonist, allosteric and antagonist modulation. As functional probes, neonicotinoids and their derivatives help underscore selectivity mechanisms and understand topological divergence in the binding sites of insects and vertebrates. This selectivity makes neonicotinoids non-toxic to vertebrates in general.

Nithiazine are neonicotinoid precursors that contain an active nitromethylene functionality that has been demonstrated to target cholinergic neurotransmission [38], ushering discovery and development of a new generation of insecticides based on their agonistic property on nAChRs. The mechanism of action of neonicotinoids and nicotinoids on nAChRs can be traced and elucidated by understanding their structural features at physiological $\mathrm{pH}$ in different protonation states. The neonicotinoids (i.e., imidacloprid) are unprotonated and exhibits selectivity to the insect nAChR, whereas the nicotinoids (i.e., nicotine) are positively charged and confers selectivity to mammalian nAChR. Neonicotinoids possess imidazolidine, thiazolidine, guanidine and analogous moieties. As a result, imidazoline and related moieties are substantially proton-free. Additionally, neonicotinoids possess an electronegative moiety that either highlights the presence of a nitro or cyano 
pharmacophore which affects potency and selectivity-illustrating strong interaction with a cationic binding subsite in the insect $\mathrm{nAChR}$ receptor. On the other hand, protonated nicotinoids command cation- $\pi$ binding to the vertebrate $n A C h R$ receptor. These marked differences due to low affinity for vertebrates relative to insect nicotinic receptors catapults neonicotinoids to having favorable toxicological profiles [39].

Identification of key amino acid residues involved during binding was demonstrated through modeling of $\mathrm{nAChR}$ receptors along with site-directed amino acid mutations of nAChRs and assessment of the mutants' neonicotinoid sensitivity. Agonist ligands present in vertebrate neurotransmitter-gated ion channels are normally cationic. Cationic iminium moieties of $\mathrm{N}$-unsubstituted imine derivatives of neonicotinoids (i.e., desnitro-IMI) interact to a $\pi$-nucleophilic subsite comprised of aromatic substructures, including a key tryptophan present in loop B of the $\alpha$-subunit. The Gln 55 residue in loop D is generally conserved as the basic amino acid residue in insect $n A C h R$ non- $\alpha$ subunits. Interactions of cyano moiety of thiacloprid and the nitro functionalities of imidacloprid and clothianidin illustrate the functional significance of the basic residue in loop $\mathrm{D}$ in determining neonicotinoid action on insect nAChRs. In agreement with this finding, the guanidine moiety of DN-IMI lacking a nitro group was pushed away from loop $\mathrm{D}$ as noted in the crystal assembly of wild-type AChBP [40]. Additionally, the nitro group of CH-IMI exhibited dual binding with Lys34 in loop G and Arg55 in loop D. This observation shows that basic amino acid residue evokes an important function for the insect nAChR-selectivity of neonicotinoid insecticides [41].

During our investigation on the toxicity of imidacloprid on non-target organisms such as Neocaridina denticulata, imidacloprid demonstrated high binding affinity to $\mathrm{nAChR}$ through a molecular docking simulation study [42]. The acetylcholine binding protein (AChBP) from the snail Lymnaea stagnalis was used for this purpose since it is considered a surrogate marker of the ligand-binding domain in nAChRs for loops A-F, which are highly conserved. The simulation results of molecular docking showed that the binding energy of imidacloprid is $-6.0 \mathrm{kcal} / \mathrm{mol}$. In contrast, the binding energy of acetylcholine was found to be weaker at $-4.2 \mathrm{kcal} / \mathrm{mol}$ to the $\mathrm{nAChR}$. The relatively strong interaction was due to conventional hydrogen bonding between the nitrogen of the pyridine moiety in imidacloprid with Trp143 and amidine N-nitro with the phenolic residue of Tyr192. In contrast, acetylcholine interacted via weak van der Waals with Trp143 of nAChR [42]. A summary of common neonicotinoids their mode of action and model organisms (invertebrates and vertebrates) is depicted in Figure 1.
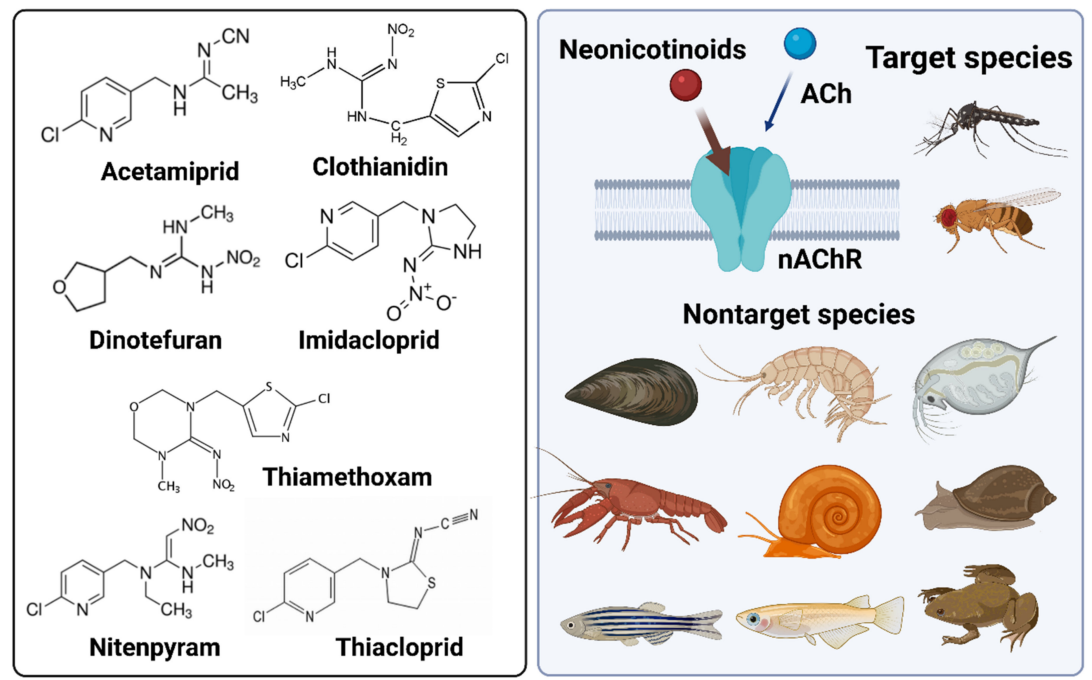

Figure 1. Summary of common neonicotinoids and invertebrate and vertebrate animal models used to test it's in vivo toxicity. The chemical structures of seven common neonicotinoid pesticides were listed in the left panel. The working mechanism and common animal models used to study neonicotinoid toxicity were listed in the right panel. 


\section{Toxicity of Neonicotinoids towards Aquatic Invertebrates}

The versatility of neonicotinoid is large considering its selective effect against arthropods and insects. They are referred to as systemic insecticides that can be utilized as sprays for crops, seed coatings, soil granules and soil drenches. Imidacloprid is the first neonicotinoid to be introduced in the market; it demonstrated low acute toxicity to typical aquatic species preferred for chemical testing [43]. Invertebrates provide a source of food for other animals, storage and transfer of metabolic energy in trophic systems, and decomposition of animal and plant materials; they also possess advantages such as diversity amongst animals for a test system, ease of culture and short generation times. Invertebrates are simple organisms and can be easily handled under standard laboratory conditions.

Invertebrate species provide a good platform to study the effects of chemical compounds. The regulatory processes are well-established in these organisms [44]. Moreover, studies illustrating the effects of insect-resistant transgenic plants on beneficial insects are limited. Experiments are maintained and viewed rapidly during monitoring to understand behavior and ecological interplay amongst plants, insects and non-target insects (natural predators) in self-restrained environments of a laboratory. In one study, two lines of transgenic oilseed rape (Brassica napus) resistant to insects were analyzed to understand side-effects on hymenopteran parasite Diaeretiella rapae and its aphid host Myzus persicae. The transgenic line expressing $\delta$-endotoxin Cry 1 Ac from Bacillus thuringenesis (Bt) providing resistance against lepidopteran and transgenic line expressing proteinase inhibitor oryzacystatin (OC-1) providing resistance against coleopteran pests depicted no significant detrimental effects of oilseed rape transgenic lines on the capability of the parasite to control aphid populations. Moreover, the sex ratio was also altered on transgenic oilseed rape lines in comparison to wild-type lines and progeny of $D$. rapae developed naturally in hosts feeding on transgenic plants. It has suggested that population-scale lab studies for risk assessment of transgenic plants allow preferable investigation of containment, insect population while maintaining environmental conditions. In addition, several experiments allowed non-target insects a choice and induced behavioral responses to transgenic plants [45]. Similarly, invertebrates provide a platform for combo species tests where multiple species from different phyla can be tested on a platform speedily on a large scale and can generate quick results.

In our previous study, we successfully demonstrated the adverse effect of imidacloprid on non-target organisms of freshwater shrimp (Neocaridina denticuata) as a new aquatic invertebrate model to test neonicotinoid toxicity [42]. Freshwater shrimp were exposed to imidacloprid depicted immobilization, reduction in heart rate, decrease in gill ventilation and death. Among several tissues compared, locomotion was identified as the most sensitive endpoint and imidacloprid can induce locomotion immobilization at a concentration as low as $31.25 \mathrm{ppb}$. In a separate study, immobilization of laboratory cultured and field-collected species of aquatic invertebrates was also observed after exposure to imidacloprid after 48 or $96 \mathrm{~h}$ in an acute toxicity study with six neonicotinoids [18].

In a similar study, imidacloprid and zinc pyrithione (Zpt) exposed to two water fleas and three species of ostracods, together with $D$. magna was explored [46]. The results were differentiated between dark and light conditions. Insignificant effects were observed on the outcome of toxicity bioassays under exposure to UV light in normal laboratory conditions; whereas, $\mathrm{LC}_{50}$ and $\mathrm{EC}_{50}$ values were two times high under the light in comparison to dark conditions after exposure to imidacloprid. The $48 \mathrm{~h} \mathrm{LC}_{50}$ of cladocerans after imidacloprid treatment (65-133 ppm) was two order magnitudes higher for ostracods. The study also suggested that mortality endpoint $\mathrm{LC}_{50}$ is not a dependable factor for consideration to rely on regarding the effects of imidacloprid in a field location, because in the experiment it was noted that paralysis effects induced by imidacloprid occurred at a much lower concentration, not depending on taxa, large differences in 100-600 folds were determined between $\mathrm{LC}_{50}$ and $\mathrm{EC}_{50}$ at similar exposures. 
The acute toxicity of old imidacloprid and new clothianidin effect was also assessed in a study over five cladoceran species Ceriodaphnia reticulate, Ceriodaphnia dubia, Daphnia pulex, Daphnia magna (Daphniidae) and Moina macrocopa (Moinidae) and later species sensitivity distribution (SSD) for cladocerans and aquatic species to the specified insecticides were compared [47]. The results obtained illustrated sensitivity to both insecticides in Ceriodaphnia $>$ Daphnia $>$ Moina in descending order. In this study, the vulnerability amidst aquatic species and test cladocerans other than cladocerans to clothianidin was analyzed and equated with $5 \%$ hazardous concentration (HC5) values on both groups of the species based on species sensitivity distribution (SSD) of the tested compound. The result revealed differences in 5\% HC5 threshold amongst tested compounds to two species indicating clothianidin to be four times lower in toxicity in comparison to imidacloprid in the case of cladocerans.

To estimate emerging contaminants, a method was used to evaluate sub-lethal behavior effects by enumerating the swimming behavior of D. pulex. The optical tracking technique was devised to measure cumulative distance and angular change amongst many swimming parameters [48]. Two prototype compounds that are acetylcholinesterase (AChE) inhibitor physostigmine were employed as prototypic compounds as AChE inhibitory insecticide, e.g., nicotine prototypical compound for insecticide (imidacloprid) was evaluated. The results showed an action mechanism analogous to insecticides frequently found in surface water. The results demonstrated sub-lethal behavior effects are concentration-dependent. The study also suggested that insecticides with similar action mechanisms yield comparable results and this method can be augmented to yield a highthroughput screening tool to understand sub-lethal toxicity effects of various chemicals.

In another study reported by Raby et al. [49], the impact of a single environmentally pertinent $24 \mathrm{~h}$ pulse of thiamethoxam and imidacloprid was tested in juvenile life stages of aquatic arthropods Neocloeon triangulifer, Chironomus, Hexagenia spp. and Hyalella azteca (Hyalellidae). Three pulse concentrations 2.5, 5, and $10 \mathrm{ppb}$ were tested for specified insecticide-arthropods combination. The immobilization was detected in N. triangulifer and C. dilutus in 8.9 and $8.8 \mathrm{ppb}$ concentrations of imidacloprid, respectively, after a $24 \mathrm{~h}$ pulse. Whereas, no effects were observed on $H$. azteca and Hexagenia spp. After an immediate imidacloprid pulse or after-treatment period, organisms were recovered and transferred to clean water. Toxic effects of short-term pulse exposure of 9 ppb imidacloprid affected sensitive insect species but thiamethoxam pulse did not depict such behavior. The study concluded that affected organisms recovered and no persisting effect on tested organisms was noted after cessation of stressing treatments.

Next, an interesting study conducted in crayfish (Procambarus clarkii) aimed to evaluate neonicotinoids insecticides of clothianidin, dinotefuran and thiamethoxam as substitutes to pyrethroids in crop rotation of rice-crayfish by analyzing acute toxicities to the early life stage of crayfish. The authors analyzed correlation amongst them with acute toxicities of pyrethroid insecticides etofenprox and lambda-cyhalothrin being carried out. The outcome indicated neonicotinoids to be less acutely toxic compared to pyrethroids in the case of crayfish; thus putting neonicotinoids to be less harmful substitutes to pyrethroids in crop rotation of rice-crayfish [50].

In a next study conducted by Van den Brink et al. [51], three neonicotinoids of thiacloprid, imidacloprid, and thiamethoxam were exposed to mayfly (Cloeon dipterum) for acute and chronic tests. The seasonal effect on the toxicity of imidacloprid on C. dipterium and five specific invertebrate species Caenis horaria (Caenidae), and Plea minutissima (Pleidae), Chaoborus obscuripes (Chaoboridae), Asellus aquaticus (Asellidae), Gammarus pulex (Gammaridae) were also observed. Thiamethoxam and imidacloprid depicted comparable acute and chronic toxicity to $C$. dipterum (winter generation). However, thiacloprid was analyzed as approximately two times as toxic. The results obtained with $C$. dipterum during the summer period demonstrated contrast with high acute and chronic toxicity of imidacloprid. The acute toxicity differs by factor 20 for $96 \mathrm{~h} 50 \% \mathrm{EC}_{50}$ and 5.4 for $28 \mathrm{~d} \mathrm{EC}_{50}$. The temperature was noted to play insignificant effects on the sensitivity of $C$. dipterum to imidacloprid as 
tests performed at 10 and $18{ }^{\circ} \mathrm{C}$ found a factor of 1.7 differences in $96 \mathrm{~h} \mathrm{EC} \mathrm{E}_{50}$ experiments. Observations suggested that if environmental fate and usage of three neonicotinoids are equivalent, substituting imidacloprid by any other neonicotinoid might not recede the environmental effect on $C$. dipterum (mayfly nymph).

In another long-term ( $28 \mathrm{~d}$ ) static renewal study on mayfly (Deleatidium spp.) after exposure to extensively used neonicotinoids namely thiamethoxam, imidacloprid and clothianidin, the endpoints of survival, molting, immobility and impairment were studied. Clothianidin and imidacloprid depicted persistent toxicity impact on Deleatidium nymphs with $\mathrm{LC}_{50}$ at $28 \mathrm{~d}$ as 1.36 and $0.28 \mathrm{ppb}$, respectively, with thiamethoxam being lowest in toxicity with $28 \mathrm{~d} \mathrm{LC}_{50}>4 \mathrm{ppb}$. The molting of mayfly was negatively affected by imidacloprid ( 2 of 4 weeks), thiamethoxam ( 1 of 4 weeks) and clothianidin ( 3 of 4 weeks) [52]. Further in an acute and chronic toxicity study with imidacloprid exposure to freshwater arthropods, it was observed that caddisfly and mayfly species were utmost sensitive to imidacloprid exposures in short-term, whereas, mayflies were most sensitive to imidacloprid (long-term). The study indicated elevated risks of chronic imidacloprid exposure to mayflies [53].

Acute and chronic toxicity testing was also investigated for thirty freshwater species (crustaceans, macrophytes, algae, insects, mollusks and fish) and four marine species (mollusk, algae, crustacean, and fish). Fish and primary producers were observed to be less sensitive to neonicotinoids, with $\mathrm{LC}_{50} / \mathrm{EC}_{50}$ found to be $\geq 80 \mathrm{ppm}$ in all cases, which surpasses exposure concentrations of surface water. Insects were sensitive at $\mathrm{EC}_{50}<1 \mathrm{ppm}$. Rotifers, worms and mollusks showed similar sensitivity $\mathrm{EC}_{50} \geq 100 \mathrm{mg} / \mathrm{L}$. Lumbriculus sp., with $\mathrm{EC}_{50} 7.7 \mathrm{ppm}$. Crustaceans exhibited sensitivity akin to insects $\mathrm{EC}_{50}<1 \mathrm{ppm}$ and midge larvae were comparably insensitive in comparison to insects $\left(\mathrm{EC}_{50}<1 \mathrm{ppm}\right)$. The most sensitive response was observed with the insect Chironomus riparius (Chironomidae) after 30 days with NOEC of $0.01 \mathrm{ppm}$. The toxicity detected to both marine and freshwater organisms was comparable [54].

In another study reported by Rico et al. [55], an equimolar mixture of five neonicotinoids (acetamiprid, imidacloprid, thiacloprid, thiamethoxam, clothianidin) and a single application of imidacloprid were exposed to aquatic invertebrates. Neonicotinoids' maximum sensitivity was observed to be below $0.2 \mathrm{ppb}$ at NOEC for Cyclopoida, Cloeon deipterum (Baetidae) and Chironomini (Chironomidae). An interesting observation of short-term exposure of a neonicotinoid mixture and a single dose of imidacloprid concentration to macroinvertebrate and zooplankton communities were comparable, which further suggested that the concentration addition model may be utilized as a reasonable hypothesis to determine a mixture of neonicotinoid in aquatic ecosystems. However, the mixture toxicity assessment on a long-term basis should be considered to understand the outcome of assessed substances in the concerned environment.

Further temperature and time relationships were studied to understand the effect of imidacloprid toxicity on lotic mayfly Isonychia bicolor (Isonychiidae) whereby underlying mechanisms of temperature-intensified toxicity including imidacloprid uptake, metabolic rate and tissue bio-concentration were investigated. The temperature impact was conducted at range 15, 18, 21 and $24{ }^{\circ} \mathrm{C}$ where $96 \mathrm{~h} \mathrm{EC}_{50}$ (immobility) was $5.81 \mathrm{ppb}$ approximately 3.2-fold less than concentration related with $50 \%$ mortality. The other tested parameters such as time to effect sub-lethal immobility and impairment were significantly lowered with an increase in temperature. The study established the temperature to be a strong modulator of sub-lethal toxicity in environmentally pertinent temperatures, affecting uptake as well as metabolic rates of I. bicolor. The research group also made an additional observation with aquatic invertebrates (including Neocloeon triangulifer, Macaffertium modestum, I. bicolor, Acroneuria carolinensis, Pleuroceridae spp. and Pteronarcys proteus) to contextualize and confirm finding from basic experiments. The most important observation made by the research group emphasizes that imidacloprid uptake is altered by temperature across a range of species representing variation in physiology between aquatic invertebrate communities as the challenge of relying exclusively on surrogate species [56]. 
In another research work carried out by Macaulay et al. [57], the effect of the individual and interactive impact of imidacloprid and the water temperature was studied on mayflies Coloburiscus humeralis (Coloburiscidae) and Deleatidium spp. The $96 \mathrm{~h}$ bioassays were performed at $9,12,15,18,21$ and $24{ }^{\circ} \mathrm{C}$. The results showed impairment and molting in mayfly with a synergistic increase in mayfly immobility and mortality after exposing them to imidacloprid at high temperatures, suggesting elevated toxicity of imidacloprid under the influence of high temperature. Moreover, mortality of Coloburiscus humeralis and Deleatidium spp. was synergistically lowered by a combination of imidacloprid exposure and increasing temperatures. Similar interaction also affected the molting frequency of Deleatidium and the mobility of $C$. humeralis. In a similar study, a multiple stressor approach was performed to investigate individual and combined chronic toxicity of imidacloprid, thiamethoxam and clothianidin in a 28 days investigation on Deleatidium spp. The result indicated that imidacloprid lowered mayfly mobility $100 \%$ and survival by $50 \%$ at 28 days which is high in comparison to clothianidin and thiamethoxam. Interaction of imidacloprid with other two neonicotinoids in this study caused greater than additive negative effect when combined until exposure day 25 . The results of this work emphasized the high toxicity of imidacloprid to non-target insects in comparison to thiamethoxam and clothianidin [58].

In another study reported by Bartlett et al. [59], six neonicotinoids namely acetamiprid, imidacloprid, thiacloprid, clothianidin, dinotefuran and thiamethoxam, were used to assess acute and chronic toxicity on the freshwater organism of amphipod (H. azteca). Toxicity was dependent on the composition of the compound, as acetamiprid and clothianidin were toxic at acute (7 days) survival and thiamethoxam and imidacloprid being least toxic. In the case of chronic exposure (28 days), survival and growth of $H$. azteca were affected at the same concentrations as acute survival, but $\mathrm{LC}_{50}$ was reduced between 7 and 28 days for imidacloprid and thiacloprid. Six neonicotinoids thiamethoxam, acetamiprid, imidacloprid, dinotefuran, thiacloprid, and clothianidin, and were also exposed to Hexagenia spp. The mobility of Hexagenia was affected at imidacloprid, thiacloprid and acetamiprid concentration of $1 \mathrm{ppb}-780-6200$ times less than $\mathrm{LC}_{50}$ and 4-10 times less than $\mathrm{EC}_{50}$. The effect on growth and survival was observed to reduce significantly at $10 \mathrm{ppb}$ of acetamiprid and thiacloprid. The sub-lethal impact on mobility and behavior of Hexagenia were detected after 21 days recovery period at a concentration as low as $1-10 \mathrm{ppb}$ which is near the maximal range of concentrations of North American surface waters as stated by monitoring studies [60].

Further in a study C. riparius (a non-biting midge) when exposed to imidacloprid exhibited high sensitivity with $24 \mathrm{~h} \mathrm{LC} \mathrm{L}_{50} 31.45 \mathrm{ppb}$ and 10 days LOEC $0.625 \mathrm{ppb}$. Interestingly, sub-lethal exposure caused an imbalance in oxidized and reduced glutathione of Glutathione disulfide (GSSG) and Glutathione (GSH) and increment in malondialdehyde (MDA) levels with reduction of lipid peroxidation; indicating oxidative stress-a relevant mechanism of neonicotinoid toxicity during insect development and life cycle [61].

A study was also conducted over Chironomus dilutus to analyze major modes of action (MOAs) of imidacloprid. After $96 \mathrm{~h}$ of exposure lethal and sub-lethal outcomes were assessed in the midge [62]. De novo RNA sequencing technique was used to identify conventional and additional MOAs toxicity pathways caused by exposure of imidacloprid to non-target aquatic species. The major MOAs identified were $\mathrm{Ca} 2 \mathrm{~b}$ homeostasis imbalance and mitochondrial dysfunction through activation of nAChRs. It was also stated that disrupted $\mathrm{Ca} 2 \mathrm{~b}$ signaling may block transduction of cAMP from ATP and prohibit LTP pathway analogous to memory and learning whereas, dysfunctional mitochondrial might also cause interruption of AMPK signaling and oxidative stress. The induction of DNA damage through oxidative stress might eventually cause the death of organisms. 
The toxicity of three neonicotinoids namely clothianidin (CLO), imidacloprid (IMI), and thiamethoxam (TMX) was studied on aquatic insect communities on single as well as binary treatment (CLO-TMX, IMI-CLO, IMI-TMX). The result after exposure on day 28 indicated collective Chironomidae emergence and no significant difference between the treatment group and control groups; whereas after 56 days significant emergence on cumulative biomass was observed for IMI, CLO and CLO-TMX. A mixture of neonicotinoids were comparably toxic compared to a single compound under semi-controlled field settings [63]. Similarly in a study with imidacloprid, clothianidin and thiamethoxam, toxicity tests were performed over $C$. dilutus full life cycle in static renewal protocol for 14 and 40 days. The results revealed advanced emergence timings, reduction in emergence success, and male inclined sex ratios to be sensitive feedback to neonicotinoids' low-level exposure. The Toxic Equivalency Factor (TEFs) and population relevant endpoints suggest clothianidin and imidacloprid exert equivalent chronic toxicity to $C$. dilutus, however, thiamethoxam induces similar effects only on concentrations that are higher in order of magnitude [64].

Further neonicotinoids risk to odonates exposing them to Ischnura elegans (Coenagrionidae) were analyzed at environmental pertinent concentrations of thiacloprid on various endpoints, using naturally colonized experimental ditches and cage environments for control field observations. The sensitivity was also assessed on a parameter of feeding damselfly with prey (lab-culture) or allowing free feeding on natural aquatic invertebrates. All the sub-lethal determinant factors were affected to some degree and were observed to be dependent on offered food. The freely feeding damselfly emerged to be highly sensitive compared to culture fed damselflies. Accordingly, results depict neonicotinoids to perform a central role in the decline of odonate [65].

A 7-day life cycle (static-renewal) for six neonicotinoids (clothianidin, acetamiprid, thiacloprid, thiamethoxam, dinotefuran, imidacloprid) with C. dubia and 21-day test with imidacloprid exposure to water flea D. magna was performed by Raby et al. [66]. D. magna expressed lower sensitivity than C. dubia after exposure to imidacloprid by 1.5-fold for reproduction and 4-fold for lethality, although the ratio for acute to chronic was observed to be comparable. However, the concentration values to trigger toxicity in C. dubia and D. magna were higher than concentrations recorded in the environment; hence toxicity resulted in these species in this experiment might be insignificant.

The effect of neonicotinoid was also observed during juvenile stages of two mollusks of Lampsilis fasciola (Unionidae) and Planorbella pilsbryi (Planorbidae). Early life stages of $P$. pilsbryi were exposed to thiamethoxam, imidacloprid, or clothianidin, for 7 or 28 days and endpoints of biomass production, growth and mortality were analyzed. The larvae of $L$. fasciola exposed to neonicotinoids (thiacloprid, thiamethoxam, acetamiprid, clothianidin, dinotefuran or imidacloprid) $48 \mathrm{~h}$ were analyzed for viability. The results demonstrated growth and biomass production to be more sensitive endpoints in comparison to mortality. Exposure to neonicotinoids was shown to pose less risk in comparison to mortality in studied mollusks in comparison to probable vulnerability to non-target aquatic insects [67].

Furthermore, a combination of competition and saturation binding sites was performed to understand the binding properties of neonicotinoid to $\mathrm{nAChR}$ in larval and adult $C$. dilutus and $C$. riparius. Radiolabeled imidacloprid $\left(\left[{ }^{3} \mathrm{H}\right]-\mathrm{IMI}\right)$ was used to characterize and compare imidacloprid receptor binding affinity $\left(\mathrm{K}_{\mathrm{i}}\right)$, binding affinity $\left(\mathrm{K}_{\mathrm{D}}\right)$, and the receptor density $\left(\mathrm{B}_{\max }\right)$ to specified neonicotinoid competitors namely clothianidin, thiamethoxam, and imidacloprid. The results in the study revealed finite differences in binding of neonicotinoid amidst $C$. dilutus and $C$. riparius, with organisms depicting greater affinity for imidacloprid and high receptor densities. The observation highlighted the significant difference amongst larvae that expressed high imidacloprid affinity and higher density of $\mathrm{nAChRs}$ in comparison to adults. Differences in neonicotinoid binding at receptor-level was speculated to be responsible for eco-toxicological differences between insect, life stages and compound-specific binding properties which can further aid to enhance the practices of risk assessment for neonicotinoids and other nAChR selective 
insecticides during registration, risk assessment and regulation of product to understand harmful effects linked with unintentional neonicotinoid exposure [68].

Sub-lethal effects of imidacloprid in two salinity treatments in a study were observed over immunity parameters of Sydney rock oysters Saccostrea glomerata (Ostreidae) for acute toxicity study in 4 days monitoring. The results demonstrated that imidacloprid induced GST activity, reduced HA, inhibited AChE activity and increased THC levels. Moreover, at $\geq 0.01 \mathrm{ppm}$ significant alteration of expression of 28 proteins in hemolymph with an increase in expression of severin, superoxide dismutase, stress response to proteins, ATP synthase subunit beta and decrease in metalloendopeptidase, L-ascorbate oxidase transporter and collagen alpha- 4 and alpha- 6 were noted. Overall, the study indicated that the immune system of $S$. glomerata was impaired at an environmentally pertinent concentration of imidacloprid, however, reduction in salinity did not influence the toxicity of this insecticide [69].

Next in a study reported by Butcherine et al. [70], four neonicotinoids clothianidin, acetamiprid, thiamethoxam and imidacloprid were also exposed to juvenile Penaeus Monodon (Penaeidae) for an uptake ( $8 \mathrm{~d}$ ) and elimination (4 d) studies. Levels of acute toxicity, uptake, and depuration were explored. Acute toxicity was observed to be in the order acetamiprid $<$ imidacloprid $<$ thiamethoxam $<$ clothianidin. The lower accumulation in tissue may be attributed to low toxicity caused by acetamiprid. The elimination time period reduced the activity of oxidative stress enzyme and tissue concentration of active ingredients. Acetamiprid depicted a reduction in enzymatic activity and caused no acute toxicity on P. monodon; therefore, it may be a relevant substitute to other neonicotinoids in the areas of shrimp production. In a similar study, adverse effects of imidacloprid were studied on the nutritional quality of $P$. monodon. Shrimps were exposed to imidacloprid in water at 5 and $30 \mathrm{ppb}$ or through food 12.5 and $75 \mu \mathrm{g} / \mathrm{g}$. Shrimp accumulated imidacloprid $0.350 \mu \mathrm{g}$ per g body weight from food and water exposure within $4 \mathrm{~d}$ of exposure; whereas chronic exposure revealed a significant decrement in total lipid content and body weight. Modification of fatty acids was also observed in exposed shrimps. The study indicated that exposure to neonicotinoids might lead to nutrient insufficiency which may interfere with shrimp productivity and its food quality [71].

Another study on P. monodon at larval and post-larval stages suggested that shrimp is most susceptible to the impact of pesticides because of their rapid growth requirements and high surface volume ratio. To evaluate this risk toxicity in $20 \mathrm{~d}$ post-hatch postlarval P. monodon was performed exposing them to imidacloprid, bifenthrin and fipronil which showed a decrease in survival and feeding inhibition. Interestingly, it was observed that post-larval shrimp were sensitive to imidacloprid, fipronil, at similar concentrations that may cause mortality in other crustaceans. The reduction in the capability of larvae shrimp to seize live prey at environment-relevant concentration exposure to imidacloprid was observed. Overall, the study suggested the prospect of indirect or mixture-related impacts [72]. We summarized the studies of prominent harmful effects of neonicotinoid insecticides on aquatic invertebrates in Table 1. 
Table 1. The potential adverse effects of neonicotinoid insecticides on aquatic invertebrates.

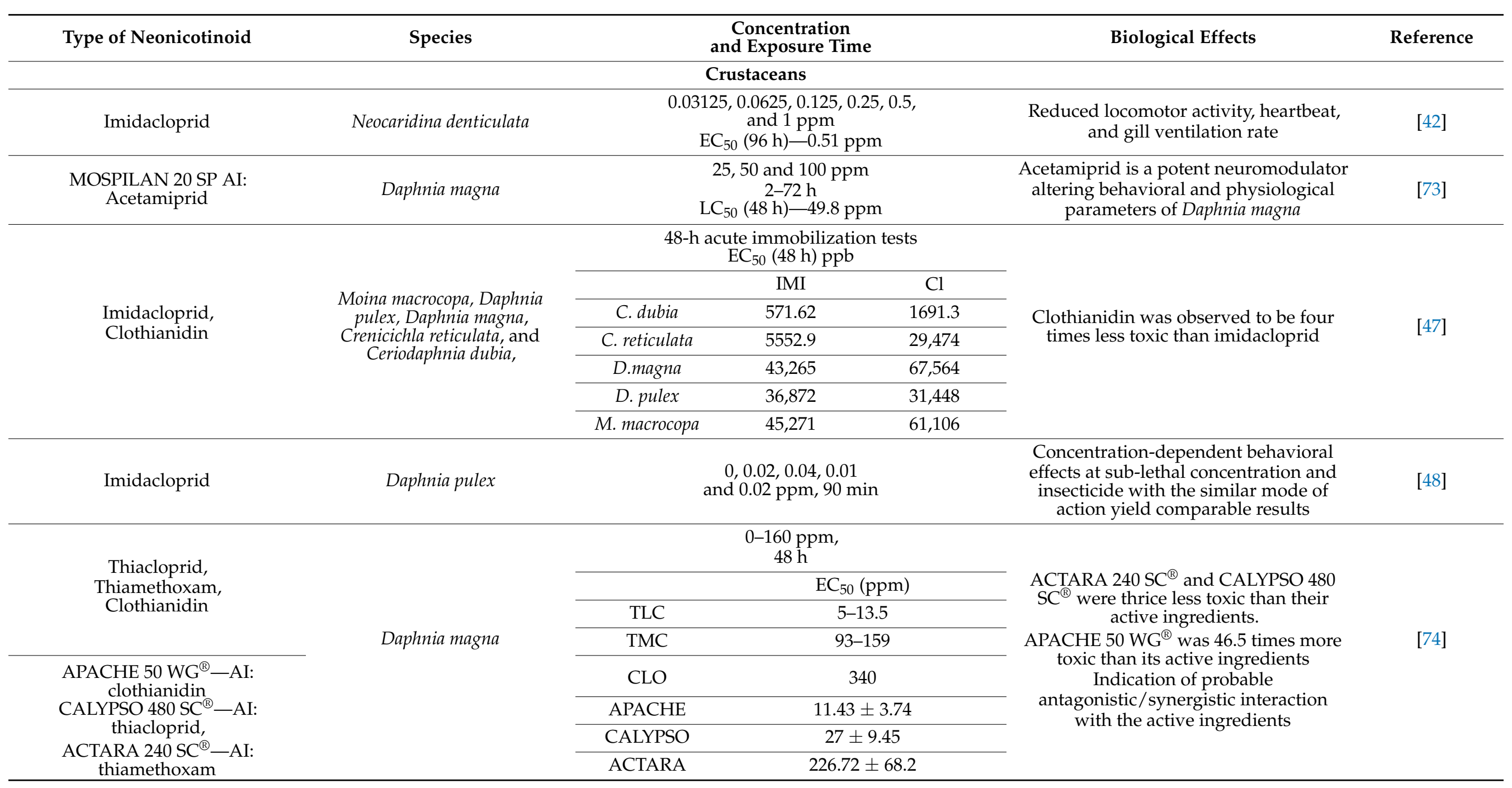


Table 1. Cont.

\begin{tabular}{|c|c|c|c|c|}
\hline Type of Neonicotinoid & Species & $\begin{array}{c}\text { Concentration } \\
\text { and Exposure Time }\end{array}$ & Biological Effects & Reference \\
\hline \multirow{2}{*}{$\begin{array}{l}\text { Imidacloprid, } \\
\text { Thiamethoxam }\end{array}$} & \multirow{2}{*}{$\begin{array}{c}\text { Hexagenia spp., Hyalella azteca, } \\
\text { Neocloeon triangulifer } \\
\text { and Chironomus dilutus }\end{array}$} & $\begin{array}{l}2.5,5, \text { and } 10 \mathrm{ppb} \\
24 \mathrm{~h}\end{array}$ & \multirow{2}{*}{$\begin{array}{l}\text { Imidacloprid at } \sim 9 \mathrm{ppb} \text { caused toxicity } \\
\text { impact due to short-term pulse in } \\
\text { sensitive insect spp. No persistent } \\
\text { impact on test organisms after cessation } \\
\text { of stressor } \\
\end{array}$} & \multirow{2}{*}{ [49] } \\
\hline & & $\begin{array}{c}\text { Hexagenia spp. } \mathrm{EC}_{50}(96 \mathrm{~h})<50 \mathrm{ppb} \\
\text { N. triangulifer } \mathrm{EC}_{50} 96 \mathrm{~h}<10 \mathrm{ppb}\end{array}$ & & \\
\hline \multirow{8}{*}{$\begin{array}{l}\text { Imidacloprid, } \\
\text { Thiacloprid, } \\
\text { Thiamethoxam }\end{array}$} & \multirow{8}{*}{$\begin{array}{l}\text { Plea minutissima, } \\
\text { Caenis horaria, } \\
\text { Cloeon dipterum } \\
\text { Chaoborus obscuripes } \\
\text { Asellus aquaticus } \\
\text { Gammarus pulex }\end{array}$} & $\begin{array}{c}\text { Acute: } 0.3,1,3,10,30,100,300 \mathrm{ppm}-24,48,72, \\
\text { and } 96 \mathrm{~h}\end{array}$ & \multirow{8}{*}{$\begin{array}{l}\text { Thiamethoxam and imidacloprid } \\
\text { depicted comparable acute and chronic } \\
\text { toxicity to C. dipterum winter generation; } \\
\text { however, thiacloprid was observed two } \\
\text { times as toxic }\end{array}$} & \multirow{8}{*}{ [51] } \\
\hline & & IMI & & \\
\hline & & TLC & & \\
\hline & & $\begin{array}{ll}\text { TMC } & 20\end{array}$ & & \\
\hline & & $\begin{array}{c}\text { Chronic: } 0.01,0.03,0.1,0.3,1,3 \mathrm{ppm} \\
\text { Day } 7,14,21, \text { and } 28\end{array}$ & & \\
\hline & & $\mathrm{EC}_{50}(\mathrm{ppm})$ & & \\
\hline & & 0.68 & & \\
\hline & & TMC & & \\
\hline \multirow{5}{*}{$\begin{array}{l}\text { Imidacloprid, } \\
\text { Clothianidin, } \\
\text { Thiamethoxam. }\end{array}$} & \multirow{5}{*}{$\begin{array}{l}\text { Mayfly } \\
\text { Deleatidium spp. }\end{array}$} & $\begin{array}{l}0 \text { to } 4 \mathrm{ppb} \\
\quad 28-\mathrm{d}\end{array}$ & \multirow{5}{*}{$\begin{array}{l}\text { Clothianidin and imidacloprid depicted } \\
\text { strong chronic toxicity impact on } \\
\text { Deleatidium nymphs }\end{array}$} & \multirow{5}{*}[52]{} \\
\hline & & $\mathrm{EC}_{50}(\mathrm{ppb})$ & & \\
\hline & & 0.19 & & \\
\hline & & $\mathrm{CLO}$ & & \\
\hline & & TMC & & \\
\hline
\end{tabular}


Table 1. Cont.

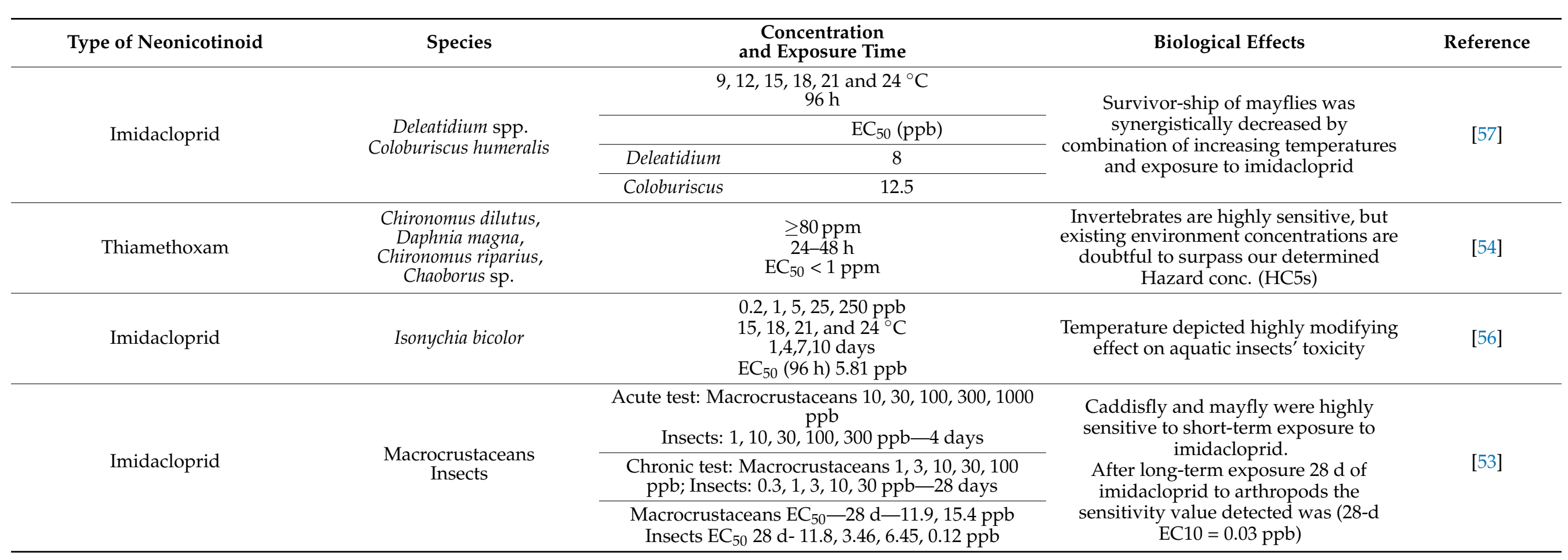


Table 1. Cont.

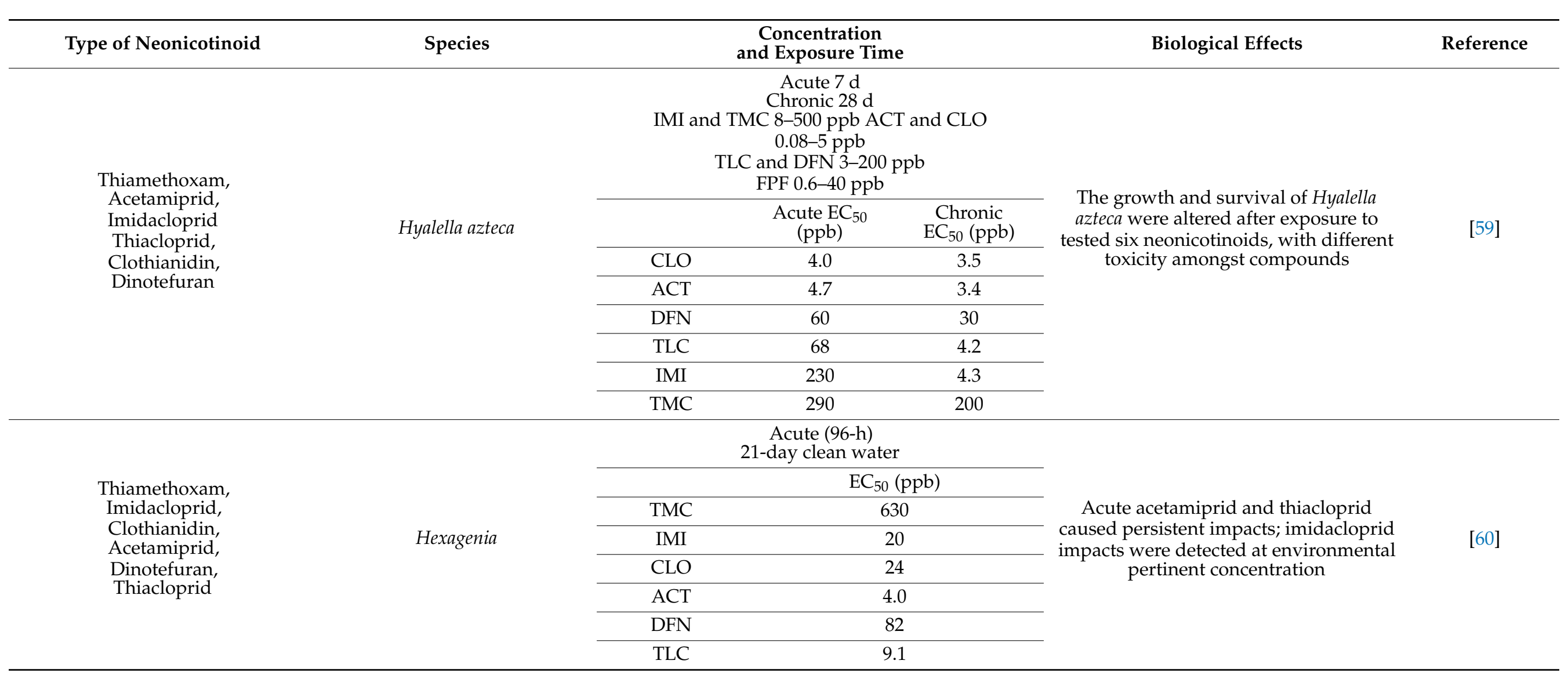


Table 1. Cont.

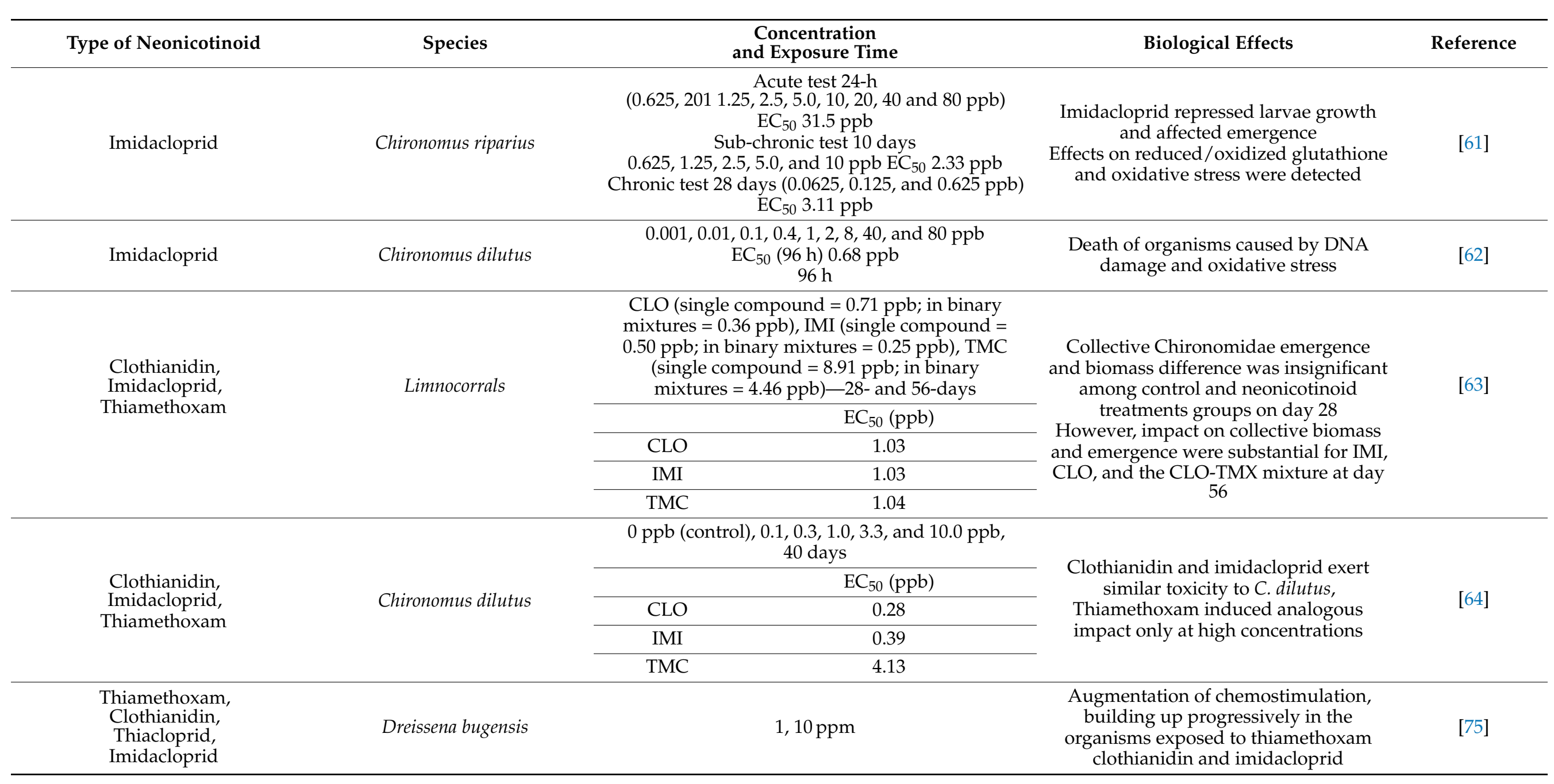


Table 1. Cont.

\begin{tabular}{|c|c|c|c|c|c|c|}
\hline Type of Neonicotinoid & Species & \multicolumn{3}{|c|}{$\begin{array}{c}\text { Concentration } \\
\text { and Exposure Time }\end{array}$} & Biological Effects & Reference \\
\hline Thiacloprid & Ischnura elegans & \multicolumn{3}{|c|}{$\begin{array}{c}0 \text { (control), } 0.1,1 \text { and } 10 \mathrm{ppb} \\
40 \text { days } \\
\mathrm{EC}_{50} 1.04 \mathrm{ppb}\end{array}$} & $\begin{array}{l}\text { Environmental pertinent thiacloprid } \\
\text { concentrations considerably decline } I \text {. } \\
\text { elegans emergence }\end{array}$ & [65] \\
\hline \multirow{7}{*}{$\begin{array}{l}\text { Dinotefuran, } \\
\text { Clothianidin, } \\
\text { Imidacloprid, } \\
\text { Thiamethoxam, } \\
\text { Acetamiprid, } \\
\text { Thiacloprid }\end{array}$} & \multirow{7}{*}{$\begin{array}{l}\text { Ceriodaphnia dubia, } \\
\text { Daphnia magna }\end{array}$} & $\begin{array}{r}100,50,25 \\
50,25,12.5 \\
\end{array}$ & $\begin{array}{l}25,3.12 \\
12,1.56\end{array}$ & $\begin{array}{l}-7 \text { days } \\
-21 \text { days }\end{array}$ & \multirow{7}{*}{$\begin{array}{l}\text { Neonicotinoids depicted chronic toxicity } \\
\text { to } \\
\text { C. dubia and D. magna at }>1 \mathrm{ppm}\end{array}$} & \multirow{7}{*}{ [49] } \\
\hline & & & & $\mathrm{C}_{50}(\mathrm{ppm})$ & & \\
\hline & & D. magna & IMI & 4.59 & & \\
\hline & & \multirow{4}{*}{ C. dubia } & ACT & 12.95 & & \\
\hline & & & CLO & 14.52 & & \\
\hline & & & IMI & 2.98 & & \\
\hline & & & TLC & 2.06 & & \\
\hline $\begin{array}{l}\text { CALYPSO } 480 \text { SC (CAL) } \\
\text { AI: thiacloprid }\end{array}$ & Cherax destructor & \multicolumn{3}{|c|}{$\begin{array}{l}0.1,0.5,1,5,10,25 \text {, and } 50 \mathrm{ppm} \\
24 \mathrm{~h}, 48 \mathrm{~h}, 72 \mathrm{~h} \text {, and } 96 \mathrm{~h} \\
\mathrm{LC}_{50}(96 \mathrm{~h}) 7.7 \mathrm{ppm}\end{array}$} & $\begin{array}{l}\text { Antioxidant enzyme activity } \\
\text { demonstrated considerable alteration in } \\
\text { hepatopancreatic tissues }\end{array}$ & [76] \\
\hline \multirow{8}{*}{$\begin{array}{l}\text { Clothianidin, } \\
\text { Imidacloprid, } \\
\text { Thiamethoxam }\end{array}$} & \multirow{8}{*}{$\begin{array}{l}\text { Chironomus riparius and } \\
\text { Chironomus dilutus } \\
\text { (larva and adult) }\end{array}$} & & $\begin{array}{l}\text { riparin } \\
00-217 \\
00-217, \\
640-38, \\
4 . \text { dilutu } \\
400-24 \\
400-24, \\
530-35\end{array}$ & & \multirow{8}{*}{$\begin{array}{c}\text { Binding affinity varied depending on } \\
\text { life stage and type of neonicotinoid } \\
\text { competitor } \\
\text { Differential neonicotinoid toxicity in } \\
\text { insects is driven by nicotinic receptor } \\
\text { binding }\end{array}$} & \multirow{8}{*}{ [68] } \\
\hline & & \multicolumn{3}{|c|}{$\mathrm{EC}_{50}(\mathrm{ppb})$} & & \\
\hline & & \multirow[t]{3}{*}{ C. riparius } & IMI & 12.94 & & \\
\hline & & & CLO & 21.80 & & \\
\hline & & & TMC & 55.50 & & \\
\hline & & \multirow[t]{3}{*}{ C. dilutus } & IMI & 4.63 & & \\
\hline & & & CLO & 3.30 & & \\
\hline & & & TMC & 45.0 & & \\
\hline
\end{tabular}


Table 1. Cont.

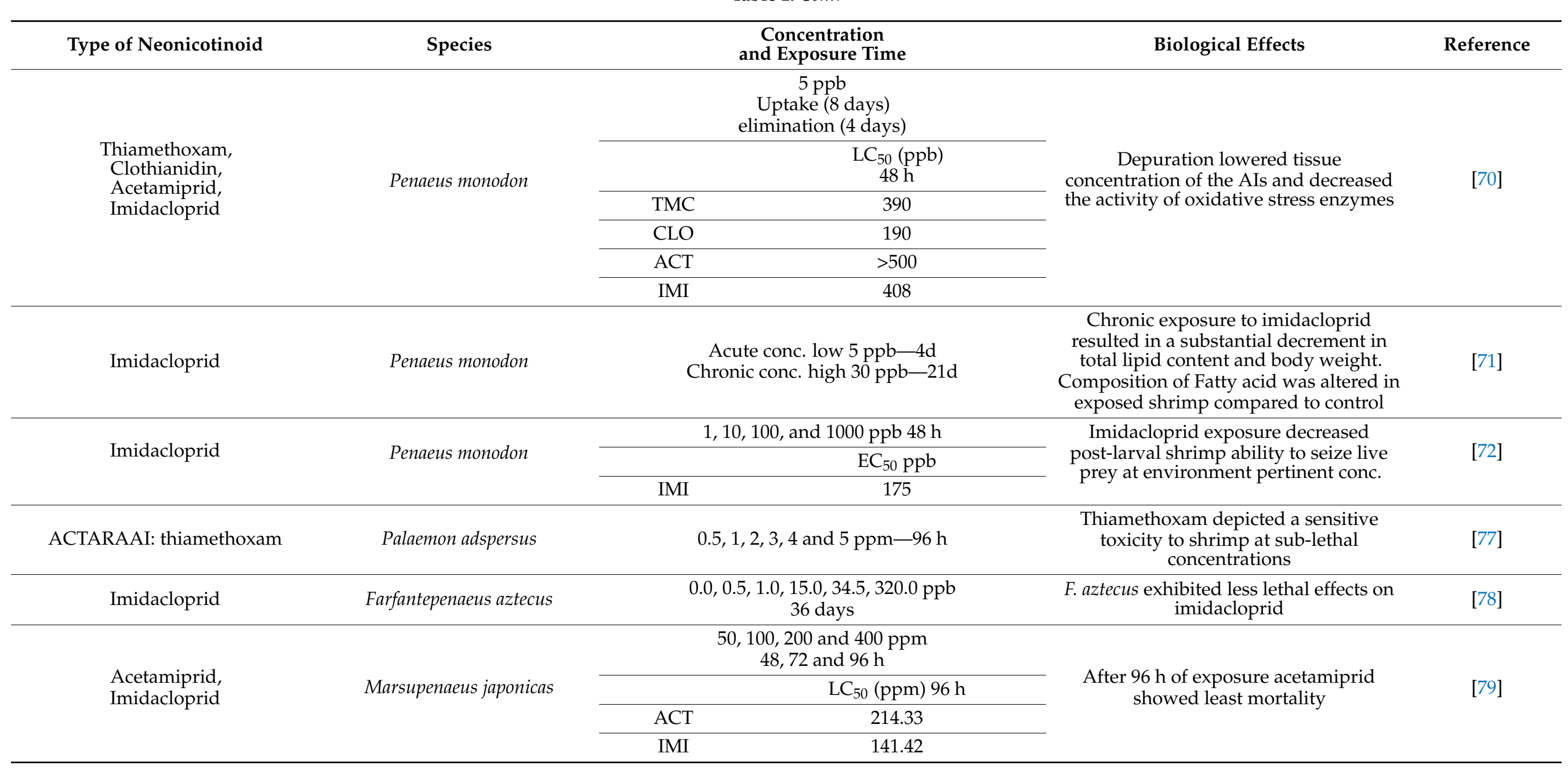


Table 1. Cont.

\begin{tabular}{|c|c|c|c|c|}
\hline Type of Neonicotinoid & Species & $\begin{array}{c}\text { Concentration } \\
\text { and Exposure Time }\end{array}$ & Biological Effects & Reference \\
\hline \multicolumn{5}{|c|}{ Molluscs } \\
\hline \multirow[t]{2}{*}{$\begin{array}{c}\text { CALYPSO } 480 \text { SC (CAL) AI: } \\
\text { thiacloprid }\end{array}$} & \multirow[t]{2}{*}{ Mytilus galloprovincialis } & $\begin{array}{l}1,10 \text { and } 100 \text { ppm } \\
20 \text { days exposure } \\
10 \text { days recovery }\end{array}$ & \multirow{2}{*}{$\begin{array}{c}\text { Sub-chronic exposure to the } \\
\text { neonicotinoid insecticide caused } \\
\text { significant alterations in cell and tissue } \\
\text { parameters }\end{array}$} & \multirow[t]{2}{*}[80]{} \\
\hline & & 96 h LC50-7.77 ppm & & \\
\hline $\begin{array}{l}\text { Imidacloprid, } \\
\text { Clothianidin, } \\
\text { Thiamethoxam }\end{array}$ & $\begin{array}{l}\text { Planorbella pilsbryi } \\
\text { Lampsilis fasciola }\end{array}$ & $\begin{array}{c}7 \text { days } 10,50,100,500,1000,5000 \text {, and } 10,000 \mathrm{ppb} \\
\text { or } 28 \text { days } 10,50,100,500 \text {, and } 1000 \mathrm{ppb} \\
\mathrm{EC}_{50} 33.2 \text { to } 122.0 \mathrm{ppb}\end{array}$ & $\begin{array}{l}\text { Growth was sensitive endpoint of } \\
\text { exposure in comparison to mortality for } \\
\text { juvenile snails }\end{array}$ & {$[67]$} \\
\hline $\begin{array}{l}\text { MOSPILAN, AI: } \\
\text { acetamiprid, } \\
\text { KOHINOR, AI: } \\
\text { imidacloprid, } \\
\text { APACS, AI: } \\
\text { clothianidin, } \\
\text { ACTARA, AI: } \\
\text { thiamethoxam, } \\
\text { CALYPSO, AI: } \\
\text { thiacloprid, }\end{array}$ & Lymnaea stagnalis & 10-1000 ppm & $\begin{array}{l}\text { Thiacloprid at } 10 \text { ppm was able to block } \\
\text { almost } 90 \% \text { of excitatory post-synaptic } \\
\text { potentials (EPSPs), whereas } \\
\text { thiamethoxam } 100 \text { ppm lowered the } \\
\text { synaptic responses by about } 15 \%\end{array}$ & [81] \\
\hline Imidacloprid & Saccostrea glomerata & $\begin{array}{c}0.01,0.1 \text {, and } 1 \text { ppm } \\
4 \text { days }\end{array}$ & $\begin{array}{l}\text { Imidacloprid causes stress at }<0.1 \mathrm{ppm} \\
\text { No synergistic impact of imidacloprid } \\
\text { was observed with reduced salinity }\end{array}$ & [69] \\
\hline \multicolumn{5}{|c|}{ Annelids } \\
\hline $\begin{array}{l}\text { Imidacloprid and Commercial } \\
\text { formulation CONFIDOR }\end{array}$ & Lumbriculus variegatus & $\begin{array}{c}0.1,1 \text { and } 10 \mathrm{IMI} \text { ppb } \\
24 \mathrm{~h} \text { and } 5 \mathrm{~d} \\
\mathrm{LC}_{50}(24 \mathrm{~h})-65(\mathrm{IMI}) \text { and } 88(\text { CONFIDOR }) \mathrm{ppb}\end{array}$ & $\begin{array}{l}\text { Activities of studied enzymes suggest } \\
\text { imidacloprid exposure cause oxidative } \\
\text { stress at environment relevant levels }\end{array}$ & [82] \\
\hline
\end{tabular}


Table 1. Cont.

\begin{tabular}{|c|c|c|c|c|}
\hline Type of Neonicotinoid & Species & $\begin{array}{c}\text { Concentration } \\
\text { and Exposure Time }\end{array}$ & Biological Effects & Reference \\
\hline \multicolumn{5}{|c|}{ Combo species tests } \\
\hline $\begin{array}{l}\text { Clothianidin, } \\
\text { Acetamiprid, } \\
\text { Dinotefuran, } \\
\text { Thiacloprid, } \\
\text { Imidacloprid, } \\
\text { Thiamethoxam }\end{array}$ & $\begin{array}{c}\text { Lab cultured spp. } \\
\text { Daphnia magna, Chironomus } \\
\text { dilutus, } \\
\text { Ceriodaphnia dubia, Hyalella } \\
\text { azteca, Hexagenia spp., } \\
\text { Neocloeon triangulifer and } \\
\text { Lumbriculus variegatus } \\
\text { Field collected spp. } \\
\text { Ephemeroptera, Trichoptera, } \\
\text { Coleoptera, Isopoda, Hemiptera, } \\
\text { Odonata, Diptera, Plecoptera, } \\
\text { Agnetina sp. and Paragnetina } \\
\text { sp. }\end{array}$ & $\begin{array}{l}\text { Target compounds in aqueous environmental } \\
\text { matrices were measured without sample } \\
\text { concentration by direct aqueous injection } \\
\text { (injection volume of } 90 \mu \mathrm{L} \text { ), and where results } \\
\text { exceeded the calibration range of an analyte } \\
0.5-2 \mathrm{ppb} \text { for different analytes } \\
48 \mathrm{~h}-96 \mathrm{~h}\end{array}$ & $\begin{array}{l}\text { Most sensitive insects Chironomus dilutus } \\
\text { and Neocloeon triangulifer. Whereas } \\
\text { Ceriodaphnia dubia and Daphnia magna } \\
\text { were the least sensitive. Neonicotinoids } \\
\text { except imidacloprid showed no harmful } \\
\text { effect in terms of acute toxicity } \\
\text { Imidacloprid, was found hazardous on } \\
\text { invertebrate immobilization, and not } \\
\text { lethality }\end{array}$ & [18] \\
\hline $\begin{array}{c}\text { Imidacloprid } \\
\text { Mix. of five Neonicotinoids } \\
\text { Imidacloprid, } \\
\text { Thiacloprid, } \\
\text { Clothianidin, } \\
\text { Acetamiprid, } \\
\text { Thiamethoxam }\end{array}$ & $\begin{array}{c}\text { Macroinvertebrates- } \\
\text { molluscs (5 taxa), insects } \\
\text { (26 taxa), platyhelminthes } \\
\text { (2 taxa), arachnid (1 taxon), } \\
\text { annelids ( } 3 \text { taxa), crustacean } \\
\text { (1 taxon) }\end{array}$ & $\begin{array}{c}(0.2,1,5,25,250 \mathrm{ppb}) \\
1,4,7,10 \text { days } \\
\left(-20^{\circ} \mathrm{C}\right)\end{array}$ & $\begin{array}{c}\text { Temperature emerged main } \\
\text { environment factor affecting the } \\
\text { sensitivity of } \\
\text { invertebrates-neonicotinoid } \\
\text { contamination }\end{array}$ & [55] \\
\hline $\begin{array}{l}\text { Acetamiprid, } \\
\text { Clothianidin }\end{array}$ & $\begin{array}{c}\text { Crangon uritai } \\
\text { Penaeus japonicas } \\
\text { Americamysis bahia }\end{array}$ & $\begin{array}{l}\text { Crangon uritai } 96-\mathrm{h} \mathrm{LC}_{50} \\
\text { ACT: } 4500 \mathrm{ppb} \\
\text { CLO: } 360 \mathrm{ppb} \\
\text { Penaeus japonicus 96-h LC } \text { L }_{50} \\
\text { ACT: } 85 \mathrm{ppb} \\
\text { CLO: } 89 \mathrm{ppb} \\
\text { Americamysis bahia 96-h LC } \text { L }_{50} \\
\text { ACT: } 24 \mathrm{ppb} \\
\text { CLO: } 51 \mathrm{ppb}\end{array}$ & $\begin{array}{l}\text { Treatments with the neonicotinoids and } \\
\text { oxygenase inhibitor revealed increase in } \\
\text { mortality in Crangon uritai but not in } \\
\text { Penaeus japonicas and Americamysis bahia. } \\
\text { It was concluded that oxygenase might } \\
\text { interpret the high resistance of sand } \\
\text { shrimp to neonicotinoid insecticides }\end{array}$ & [83] \\
\hline
\end{tabular}

Abbreviation: TLC—Thiacloprid, TMC—Thiamethoxam, CLO—Clothianidin, IMI—Imidacloprid, ACT—Acetamiprid, DFN-Dinotefuran, FPF—Flupyradifurone, AI—Active ingredients. 
Further in a study conducted by Bownik et al. [73], the effects of the insecticide MOSPILAN 20 SP with 20\% active ingredient: acetamiprid were studied at 25, 50 and $100 \mathrm{ppm}$ to investigate swimming velocity and physiological parameters of thoracic limb and heart in D. magna. The results in this study depicted that after $2 \mathrm{~h}$ of exposure acetamiprid induced concentration-dependent inhibition in thoracic limb activity and swimming velocity; whereas after $24 \mathrm{~h}$ of exposure, depression in heart rate at $100 \mathrm{ppm}$ was observed. The study highlighted acetamiprid persistence in water and its ability to induce cumulative toxicity. The acetamiprid was demonstrated as a potent neuromodulator altering physiological and behavioral endpoints in D. magna.

Takács et al. [74] used liquid chromatography coupled with mass spectrometry (LCMS) to study the potential toxicity of neonicotinoid-based insecticides and their active ingredients (AIs) on non-target aquatic species of D. magna. During acute immobilization tests on D. magna, dissimilarities were found amongst toxic concentrations investigated in neonicotinoids based on their specific active ingredient (AI). The toxicity of APACHE 50 $\mathrm{WG}^{\circledR}$-AI: clothianidin was observed to be 46.5 times more toxic than its AI, which might be attributed to the toxicity impact of the preparatory agent on $D$. magna. Whereas, in contrast to ACTARA 240 SC ${ }^{\circledR}$-AI: thiamethoxam; CALYPSO 480SC ${ }^{\circledR}$ - AI: thiacloprid were found to be thrice less toxic compared to their active ingredients. This indicated probable synergistic/antagonistic interconnection with active ingredients.

Furthermore, in a study reported by Vehovszky et al. [81], the toxicity of commercially available neonicotinoid imidacloprid-KOHINOR acetamiprid-MOSPILAN; clothianidinAPACS; thiamethoxam-ACTARA; thiacloprid-CALYPSO were analyzed on cholinergic synapses that prevail between VD4 and RPeD1 neurons in Lymnaea stagnalis (Lymnaeidae) central nervous system. At 10-1000 ppm, neither of the chemical responded as acetylcholine agonist instead of inhibiting cholinergic excitatory components of VD4-RPeD1 connection as they both displayed antagonist activity. Thiacloprid at $10 \mathrm{ppm}$ was observed to be able to block almost $90 \%$ of excitatory postsynaptic potentials (EPSPs), whereas thiamethoxam $100 \mathrm{ppm}$ decreased synaptic responses by $15 \%$. The ACh-induced membrane responses of RPeD1 neurons were equally impeded by neonicotinoids, pointing out that the ACh receptor target was involved. The study noted that neonicotinoids act on nicotinergic acetylcholine receptors in the central nervous system of the snail.

Commercially available insecticides with active neonicotinoids as ingredients such as ACTARA: AIs-thiamethoxam, APACS: AIs-clothianidin, CALYPSO: AIs-thiacloprid and KOHINOR: AIs-imidacloprid were used for toxicity analysis in Dreissenid mussels (D. bugensis) in vitro and in vivo. The presence of multixenobiotic resistance (MXR) mechanism and cellular defense system is well-constituted in Dreissenid mussels. The chronic exposure of APACS, ACTARA, and KOHINOR augmented gill tissues MXR activity (in vitro). The results in this study provided the first evidence for those neonicotinoid insecticides to be able to modify the transmembrane transport mechanism of the MXR system [75].

Insecticide CALYPSO 480 SC (CAL) with thiacloprid as active ingredient was exposed to yabby crayfish (Cherax destructor) at $0.1,0.5,1,5,10,25$ and 50 ppm in a study conducted by Stara et al. [76]. For assessment of antioxidant parameters superoxide dismutase, lipid peroxidation, catalase, oxidative stress, glutathione $S$-transferase and reduced glutathione in crayfish hepatopancrease, gill and muscle tissue, selected concentrations of CAL were $0.1,1,10 \mathrm{ppm}$. The crayfish demonstrated alteration in behavior in comparison to control at concentration $\geq 5 \mathrm{ppm}$ of CAL. The acute exposure of CAL further depicted a reduction in lipid peroxidation in hepatopancrease in every experiment group in comparison to the control; whereas, substantial change on glutathione $S$-transferase in hepatopancrease tissues with no difference on other antioxidant parameters in other tissues was observed as a sign of antioxidant activity. 
In another research on similar lines, the toxic effect of neonicotinoid CALYPSO 480 SC (CAL) was studied over marine invertebrate Mytilus galloprovincialis (Mytilidae) at sublethal concentrations of 1,10 and $100 \mathrm{ppm}$ and 10 days recovery period in uncontaminated seawater. The results suggested that exposure to both concentrations of CAL increased lethality rate in cells of hemolymph and digestive gland significantly, while digestive gland cells were not available to coordinate cell volume. This exposure majorly decreased hemolymph specifications $\left(\mathrm{Cl}^{-}, \mathrm{Na}^{+}\right)$and affected enzymatic activities of superoxide dismutase of digestive gland and catalase of gill, and did not cause histopathological alterations in digestive gland and gills. The histological damages detected in mussels were lipofuscin accumulation, mucous overproduction, infiltrate inflammations and focal points of necrosis. The interesting observation in the study revealed slight recovery of histological condition during the recovery period, especially in the hemocyte parameters $\left(\mathrm{K}^{+}, \mathrm{Na}^{+}, \mathrm{Ca}^{2+}\right.$, lactate dehydrogenase, and glucose). Sub-chronic exposure to neonicotinoid was noted to cause significant alteration in M. galloprovincialis at both cell and tissue parameters [80].

In a study conducted by Contardo-Jara et al. [82], imidacloprid and CONFIDOR commercial formulations of imidacloprid were assessed over Lumbriculus variegatus (Lumbriculidae) to determine bioconcentration during $24 \mathrm{~h}$ and $5 \mathrm{~d}$ exposure and dose-dependent relationship in toxicity test for $24 \mathrm{~h}$, at $0.1,1$ and $10 \mathrm{ppb}$ imidacloprid. The tissue content of imidacloprid showed a significant increment with exposure time at sub-lethal concentrations. The important observation was, bio-concentration factor was higher than the water octanol coefficient (Kow) depicting a potential false estimation of imidacloprid bioaccumulation. Activities of antioxidant enzymes and biotransformation indicate efforts of L. variegatus to counteract oxidative stress caused by low CONFIDOR and imidacloprid concentrations. Since this review only focuses on active ingredients, we recommend a thorough analysis of species-specific changes in the susceptibility of pesticides and commercial formulation additives (such as surfactants) in the future to understand environmental risk assessment.

\section{The Potential Adverse Effects of Neonicotinoid Insecticides on Aquatic Vertebrates}

The aquatic vertebrates are yet another class of organisms useful to study and understand the toxicity of chemical compounds especially insecticides at environment pertinent concentrations after exposure. Toxicity parameters and adverse effects of neonicotinoids on aquatic vertebrates have been studied intensively during the last decade to determine toxicity criteria. However, knowledge gaps need more in-depth studies. Zebrafish are among the emerging model organisms in biological disciplines. With the completion of the zebrafish genome project, zebrafish can be a subject of genetic manipulation; also, information on developmental and behavioral aspects of zebrafish provides an attractive platform for use in toxicologic studies [84,85]. While doing comprehensive research for this review paper, we also witnessed the widespread use of zebrafish as a model organism to analyze the toxicity of neonicotinoids. Medaka fish represents resilient species in aquatic models, making them ideal model organisms for study in the laboratory. With gradual transitions, they can tolerate an extensive range of temperature and salinity [86]. These vertebrate species rely on water temperature for thermoregulation and are more sensitive to disturbances brought about by climate change. Hence, considering these important factors vertebrates provide a good platform to understand toxicity parameters in aquatic model organisms. 
In a study reported by Ma et al. [26], acetamiprid was exposed to zebrafish (Danio rerio) embryos to understand developmental toxicity. The endpoints assessed were malformations, hatchability, body length, heart rate, touch response, lethal effect and alteration of spontaneous movement during $6 \mathrm{~h}$ post-fertilization (hpf) to $120 \mathrm{hpf}$. At a concentration $<263$ ppm from a range of tested concentrations, significant mortality and teratogenic effect were shown in zebrafish embryos. The main malformation observed was bent in the spine and impaired spontaneous movement in the endpoints tested. Next, in a study carried out by Lou et al. [87], adult zebrafish were exposed to imidacloprid at a concentration of 100 and $1000 \mathrm{ppb}$ for 21 days to induce oxidative stress and intestinal histopathological injury. Additionally, an increase in catalase (CAT) and superoxidase dismutase (SOD) levels was observed. Specific bacteria alterations and gut microbiota dysbiosis were also affected slightly indicating that a low concentration of imidacloprid is capable of inducing gut toxicity in adult zebrafish. In a similar study on zebrafish reported by Ge et al. [88], the toxicity of imidacloprid was assessed at a concentration range of 300, 1250 and $5000 \mathrm{ppm}$ and sampled at days 7, 14, 21 and 28 after exposure. The level of SOD, GST intensified during early exposure whereas repressed towards the end of the exposure. However, CAT levels were decreased following their upsurge through initial exposure. High concentrations of imidacloprid at 1.25 and 5 ppm induced an increase in MDA and ROS production in 21 days with DNA damage in time and dose dependent criteria, indicating that imidacloprid may induce oxidative stress and DNA damage in zebrafish.

Imidacloprid was also exposed to zebrafish to investigate the neurobehavioral effects of developmental exposure. Interestingly, nicotine was also administered in the exposure medium to analyze its effects. Zebrafish were exposed to imidacloprid or nicotine at a concentration of 2.79 or $3.72 \mathrm{ppm}$ from $4 \mathrm{~h}$ to 5 days post-fertilization. It was observed that developmental imidacloprid exposure to larvae significantly decreased swimming activity on both the given doses; whereas, in adolescent and adult fish augmented sensorimotor response to startle stimuli and declined novel tank exploration were noted. Nicotine raised sensorimotor response at a low dose but did not affect the novel tank swimming behavior. Early developmental exposure of zebrafish to imidacloprid was noted to have early life as well as persisting effects on neurobehavioral functions [89]. Zebrafish were also exposed to imidacloprid concentrations at $0,100,1000$, and 10,000 ppb for five days postfertilization. The results demonstrated increment in embryo mortality and impairment of body length with a concentration of imidacloprid in correlation with dose-dependency [90]. The DNA damage risks on zebrafish were then assessed after exposure of cyprodinil 0.31 and $0.155 \mathrm{ppm}$ and thiacloprid 1.64 and $0.82 \mathrm{ppm}$. The zebrafish were exposed to two different concentrations of cyprodinil and thiacloprid for 21 days. DNA damage was evidently found to increase in $0.31 \mathrm{ppm}$ of cyprodinil and 0.82 and $1.64 \mathrm{ppm}$ thiacloprid. Hence, the study identified cyprodinil and thiacloprid as genotoxic agents and suggests further investigation [91].

In two consecutive studies, investigation of zebrafish liver was performed after exposure to thiamethoxam $(0.30,1.25$, and $5.00 \mathrm{ppm})$ at $7 \mathrm{th}, 14 \mathrm{th}, 21 \mathrm{st}$, and 28th days and nitenpyram at $0.6,1.2,2.5$, and $5.0 \mathrm{ppm}$ for 28 days. After thiamethoxam exposure, reactive oxygen species (ROS), increased rapidly whereas, superoxide dismutase (SOD) and catalase (CAT) activities ascended initially and were inhibited. Glutathione-S-transferase (GST) activity was noted to increase on day 28 and malondialdehyde (MDA) content was raised on days 21 and 28 with a dose-dependent response along with an observation of DNA damage. Thiamethoxam was found to induce DNA damage and oxidative stress on the exposed zebrafish. Similarly, CAT and SOD were inhibited during most exposure periods. ROS, MDA and GST contents were observed to increase in zebrafish livers. Nitenpyram exposure was shown to promote DNA damage and elicit antioxidant enzymes in zebrafish $[92,93]$. 
Next in a study conducted by Wang et al. [94], the impact of single and combined pesticides ( $\lambda$-cyhalothrin, butachlor, atrazine, phoxim) was tested on zebrafish. The results from this $96 \mathrm{~h}$ semi-static study depicted that $\lambda$-cyhalothrin is most toxic to all the life stages of zebrafish with $\mathrm{LC}_{50} 0.0031-0.38 \mathrm{ppm}$. The intensity of toxicity caused by other pesticides followed from butachor, with $\mathrm{LC}_{50} 0.45-1.93 \mathrm{ppm}$. Contrastingly atrazine provided the lowest toxic effect with $\mathrm{LC}_{50} 6.09-34.19 \mathrm{ppm}$. The interesting finding in the study revealed that in combination for phoxim- $\lambda$-cyhalothrin and phoxim-atrazine showed a synergistic effect on zebrafish. The research group here suggested that chemicals are assessed individually and assumed to be toxic but it is important to understand the additive and synergistic effects of these chemicals to maintain a healthy environmental balance.

Next in a study, Zebrafish and Japanese medaka model comparative studies were observed after exposure from imidacloprid at 0.2 to $2000 \mathrm{ppb}$ and $0,0.2,2,20,200$ and $2000 \mathrm{ppb}$. It was observed that imidacloprid caused sub-lethal effects in zebrafish and Japanese medaka but impacts were stronger in medaka with deformities, lesions and reduced growth being prominent. However, in another study, except with a group exposed at $20 \mathrm{ppm}$, imidacloprid led to hyperactivity in both species. Additionally, high numbers of deformities were observed in medaka however none was detected in zebrafish. An increase in hemorrhage was noted at the highest concentration of $2000 \mathrm{ppb}$. The studies, therefore, underlined the significance of taking species sensitivity dissimilarities into account [95,96].

Parameters of genotoxicity and immunotoxicity, oxidative stress and DNA damage, of neonicotinoids namely imidacloprid, dinotefuran and nitenpyram were observed in Chinese rare minnows during chronic toxicity test $(60 \mathrm{~d})$ at a concentration of $0.1,0.5$ or $2.0 \mathrm{ppm}$. The hematological parameters demonstrated variation in the frequency of erythrocytes with micronuclei post-treatment imidacloprid at $2.0 \mathrm{ppm}$ also increment in notched nuclei and bi-nucleated erythrocytes were observed after exposure at concentration 0.5 or $2.0 \mathrm{ppm}$. The serum protein electrophoresis (SPE) displayed substantial modification in serum protein among all treatments. Biochemical assay confirmed a significant decrease in immunoglobulin $\mathrm{M}(\mathrm{IgM})$ after treatment with dinotefuran or imidacloprid at 0.5 or $2.0 \mathrm{ppm}$. The transcriptional levels of inflammatory cytokines IL-1 $\beta$, IL-6, INF- $\alpha$ and TNF- $\alpha$ were observed to be down-regulated post-treatment with imidacloprid $p<0.05$. However, the expression levels of IL- $1 \beta$ and TNF- $\alpha$ were prominently down-regulated at 0.5 and $2.0 \mathrm{ppm}$ dinotefuran treatment $p<0.05$. Imidacloprid in comparison to dinotefuran and nitenpyram was demonstrated to induce genotoxicity [97].

In a separate study reported by Tian et al. [98], oxidative stress was observed through an increase in activities of SOD in imidacloprid $(2.0 \mathrm{ppm})$, dinotefuran and nitenpyram (0.5 ppm) and CAT in $0.1 \mathrm{ppm}$ nitenpyram, but decreased in 0.1 and $2.0 \mathrm{ppm}$ dinotefuran. MDA content was observed significantly lowered in all the treatments of imidacloprid and dinotefuran treatments at $(0.5$ and $2.0 \mathrm{ppm})$, with a significant increase in nitenpyram (0.1 ppm). A substantial increment in GSH level was detected in all treatments except with dinotefuran $(0.5 \mathrm{ppm})$. DNA damage revealed a significant increase in tail moments at imidacloprid treatment $(2.0 \mathrm{ppm})$, with an increase in tail DNA by imidacloprid (0.5 and $2.0 \mathrm{ppm})$, nitenpyram $(2.0 \mathrm{ppm})$ and all dinotefuran treatments; concluding that DNA damage and oxidative stress findings depicted nitenpyram and imidacloprid can cause potential adverse effects on juvenile rare minnows.

Toxic effects of nitenpyram and imidacloprid were assessed on juvenile Chinese rare minnow brains determining oxidative stress, acetylcholinesterase (AChE) activity and 8-hydroxy-2-deoxyguanosine content. The activity of SOD did not change considerably by chronic exposure to nitenpyram and imidacloprid. An increment in the activity of CAT in brain tissues was observed under imidacloprid $(0.1 \mathrm{ppm})$ and all applied treatments of nitenpyram. MDA increased upon exposure with imidacloprid (2.0 ppm) and nitenpyram $(0.1 \mathrm{ppm})$. A significant increase in GSH content in the brain was also observed under imidacloprid ( 0.5 and $2.0 \mathrm{ppm}$ ). At nitenpyram concentration of 0.1 and $0.5 \mathrm{ppm}$, catalase expression level decreased and raised 8-OHdG level with imidacloprid (2.0 ppm). However, AChE activities increased markedly under imidacloprid at (0.5 and 
$2.0 \mathrm{ppm}$ ) and decreased with nitenpyram (2.0 ppm). Imidacloprid was shown to affect the juvenile rare minnow's brain more in comparison to nitenpyram [98]. When rare minnows were subjected to heavy metal cadmium $(\mathrm{Cd})$ and pesticides (tebuconazole and thiamethoxam) exposure, the results from a $96 \mathrm{~h}$ observation depicted the highest toxic effect in order tebuconazole $>$ thiamethoxam with $\mathrm{LC}_{50} 1.86,4.07$ and $351.9 \mathrm{ppm}$ respectively. Later, one quartet mix Cd-tebuconazole-bifenthrin-thiamethoxam, two triadic mix bifenthrin-tebuconazole-thiamethoxam, tebuconazole-thiamethoxam-Cd, and four double mixes of bifenthrin-thiamethoxam, tebuconazole-thiamethoxam, bifenthrin-tebuconazole and when exposed to rare minnows depicted synergistic effects along with equitoxic and equivalent ratio on rare minnows. This study simultaneously highlighted the impact of single and combined pesticides which elevate toxicity and affect non-target organisms which indicates the need to assess water quality standards and thorough evaluation of the joint effect of chemicals [99].

The synergistic effects of two neonicotinoids thiamethoxam and imidacloprid with natural UVR were studied on larvae of yellow perch using biomarkers and survival analysis to quantify sub-lethal and lethal effects. The results obtained depicted an interaction amongst thiamethoxam and UVR in terms of mortality of larvae. Imidacloprid increased protein content under influence of UVR with an increase in acetylcholinesterase (AChE) activity at sub-lethal levels. Reduction of lipid peroxidation was found to be associated with imidacloprid which may open a new avenue of study of neonicotinoids on proteins as well as lipid accumulation [100].

The effect of clothianidin at concentrations of $0.15,1.5,15$ and $150 \mathrm{ppb}$ in a study during a long-term 4-month study on embryonic alevin and early swim by fry sockeye salmon (Oncorhynchus nerka) was investigated. The results demonstrated an insignificant impact of clothianidin exposure on hatching, survival, growth, and deformities. However, significant genetic variations were observed in the studied endpoints such as a 4 -fold escalation in $17 \beta$-estradiol levels in the whole-body post-exposure with $0.15 \mathrm{ppb}$ test concentration whereas testosterone remained unaffected. Moreover, hepatic expression of gene encoding glucocorticoid receptor 2 was affected at exposure to clothianidin at the highest concentration [101]. In a study reported by Iturburu et al. [102], imidacloprid was exposed to Australoheros facetus (cichlid) for 24 and $48 \mathrm{~h}$ to three concentrations 100, 300 and $2500 \mathrm{ppb}$ to analyze its uptake, distribution and genotoxicity. The imidacloprid was detected in the brain, gut, gills, muscle, blood and liver of the fish. The interesting finding in the study suggested that the concentration of imidacloprid remained the same at 24 and $48 \mathrm{~h}$ whereas its concentration was detected to be higher at $48 \mathrm{~h}$ in gills, gut, liver and muscle tissue. Moreover, uptake and genotoxicity were majorly observed in the model organisms with no accumulation indicating side effects that can be harmful to non-target organisms.

In another study reported by Houndji et al. [103], acute toxicity of acetamiprid (Act) and lambda-cyhalothrin (LCh) (pyrethroid) were assessed on juvenile air-breathing catfishes (Clarias gariepinus) individually and in combination at 15 and $20 \mathrm{ppm}$. The result demonstrated lambda-cyhalothrin to be high in toxicity to C. gariepinus with $\mathrm{LC}_{50} 96 \mathrm{~h}-$ $0.00083 \mathrm{ppm}$ in comparison to acetamiprid $\mathrm{LC}_{50} 96 \mathrm{~h}-265.7 \mathrm{ppm}$. Moreover, the combined effect of Act-LCh mixture and Acer $35 \mathrm{EC}^{\circledR}$ revealed $\mathrm{LC}_{50} 96 \mathrm{~h}-0.043 \mathrm{ppm}$ and $0.21 \mathrm{ppm}$ respectively indicating that side-effects of these molecules should be monitored in addition to their contamination level as well as behavioral aspects. 
The effect of clothianidin and thiamethoxam were studied for life-history traits and survival of wood frogs Lithobates sylvaticus and leopard frogs Lithobates pipiens. An artificial pond mesocosm was used to evaluate the impact of neonicotinoids at a concentration range of 2.5 and $250 \mathrm{ppb}$ at larvae development during stages of metamorphosis. No difference amongst the control and exposed group for any assessed endpoint for either leopard or wood frogs were noted. The research work suggested that concentrations meeting and exceeding detected levels of thiamethoxam and clothianidin in surface water did not impact metamorphosis in either of the two studied frog species [104]. Furthermore, in a study reported by Keller et al. [105], imidacloprid and imidacloprid-olefin (its metabolite) were analyzed for the ability to cross blood-brain barrier in Rana pipiens northern leopard frogs in non-target organisms collected from tile wetlands with high imidacloprid concentrations and control wetlands. The model organisms from tile wetlands revealed a doubly high concentration of imidacloprid in comparison to the control group. Moreover, alteration of brain structure such as width and length of cerebellum and medulla were observed. This study suggested that imidacloprid detection in neural tissues indicate the ability of insecticide to cross blood-brain barrier which also showed a dose-response relationship under lab exposure and hence, higher loads of insecticides in the aquatic ecosystem should be kept in check to avoid harming non-target organisms and disturbing food web.

In another study on a similar model organism Rana pipiens, the exposure to clothianidin was observed at larval stages over eight weeks at $0,0.23,1,10$ and $100 \mathrm{ppb}$ to assess oxidative stress and leukocyte profiles. Clothianidin induced oxidative stress at $0.23,1$ and $100 \mathrm{ppb}$ and leukocyte changes at 1 and $10 \mathrm{ppb}$ indicating stress. No differences in development, survival, growth time or hepatosomatic index in model organisms were observed. The research workers here concluded that Rana pipiens revealed increased stress response however unclear concentration-response relation is unable to mention the effect on the overall health of these organisms [106].

Similarly, early life stages of wood frogs (Lithobates sylvaticus) were selected for studying the effect of imidacloprid or thiamethoxam at three different concentrations of 1,10 and $100 \mathrm{ppb}$ to observe escape response stimulated by heron attacks. The results demonstrated that control frogs actively responded to the stimulated attack of a predator but frogs exposed to imidacloprid at 10 and $100 \mathrm{ppb}$ were unlikely to respond and leave the attack area in comparison to controls. The behavior analysis suggests that neonicotinoids exposure during larvae development may affect the early life stages of a frog's capability to respond to predators, which might increase their vulnerability to predation [107].

Finally, the toxicity of neonicotinoids (clothianidin, acetamiprid, imidacloprid, dinotefuran) was analyzed over pre-metamorphic tadpoles of Silurana tropicalis (Pipidae). The acute toxicity test was performed for $96 \mathrm{~h}$ semi-static exposure. Exposure to insecticides of pre-metamorphic tadpoles was explored in two concentrations: 0.1 and $1.0 \mathrm{ppm}$ and treatment continued till all tadpoles in control groups reached the late pro-metamorphic stage. Tested insecticides depicted insignificant alterations in any of the evaluated parameters among the control and insecticide exposed groups [108]. We summarized the studies of potential adverse effects of neonicotinoid insecticides on aquatic vertebrates in Table 2. 
Table 2. The potential adverse effects of neonicotinoid insecticides on aquatic vertebrates.

\begin{tabular}{|c|c|c|c|c|}
\hline Type of Neonicotinoid & Species & Concentration and Time & Biological Effects & Reference \\
\hline \multicolumn{5}{|c|}{ Fish } \\
\hline Acetamiprid & Danio rerio & 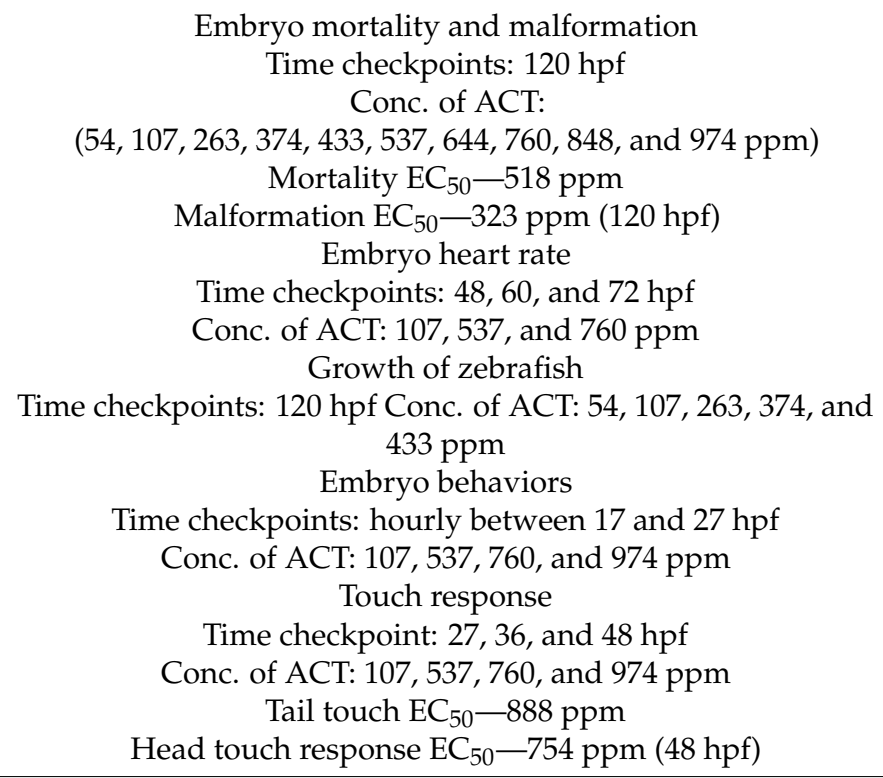 & $\begin{array}{l}\text { Zebrafish embryos exhibited significant } \\
\text { mortality ( } 120 \mathrm{hpf} \text { ) at } 374 \mathrm{ppm} \text { in } \\
\text { comparison to control groups } p<0.05, \\
\text { with absolute mortality at } 760 \mathrm{ppm} \\
\text { Acetamiprid caused different embryonic } \\
\text { defects, namely, uninflated swim } \\
\text { bladder, bent spine, yolk sac edema and } \\
\text { pericardial edema } \\
\text { Acetamiprid majorly decreased heart } \\
\text { rate of zebrafish embryos at } 48,60 \text {, and } \\
72 \text { hpf for all treatments } \\
\text { Body length of larval fish followed a } \\
\text { dose-response relationship }\end{array}$ & [26] \\
\hline \multirow{4}{*}{ Imidacloprid } & \multirow{4}{*}{ Danio rerio } & 100 and $1000 \mathrm{ppb}$ for 21 days & $\begin{array}{l}\text { IMI at low concentration indicated } \\
\text { toxicity in gut of adult zebrafish }\end{array}$ & [87] \\
\hline & & $\begin{array}{l}300,1250, \text { and } 5000 \text { ppm } \\
7,14,21 \text {, and } 28 \text { days }\end{array}$ & $\begin{array}{l}\text { Imidacloprid induced oxidative stress } \\
\text { and DNA damage in zebrafish }\end{array}$ & {$[88]$} \\
\hline & & 2.79 or $3.72 \mathrm{ppm} 4 \mathrm{~h}$ to $5 \mathrm{~d}$ after fertilization & $\begin{array}{l}\text { Imidacloprid considerably reduced } \\
\text { swimming activity in zebrafish }\end{array}$ & [89] \\
\hline & & $0,100,1,000$, and $10,000 \mathrm{ppb} 1,2,3,4,5 \mathrm{dpf}$ & $\begin{array}{l}\text { Increased embryo mortality, and } \\
\text { impairment of body length in a } \\
\text { dose-dependent association to the } \\
\text { imidacloprid concentration }\end{array}$ & {$[90]$} \\
\hline
\end{tabular}


Table 2. Cont.

\begin{tabular}{|c|c|c|c|c|}
\hline Type of Neonicotinoid & Species & Concentration and Time & Biological Effects & Reference \\
\hline Thiamethoxam & Danio rerio (livers) & $\begin{array}{l}0.30,1.25, \text { and } 5.00 \mathrm{ppm} \\
7,14,21 \text { and } 28 \text { days }\end{array}$ & $\begin{array}{l}\text { Thiamethoxam could induce DNA } \\
\text { damage and oxidative stress on the } \\
\text { treated zebrafish }\end{array}$ & [92] \\
\hline Nitenpyram & Danio rerio (livers) & $\begin{array}{l}0.6,1.2,2.5, \text { and } 5.0 \mathrm{ppm} \\
28 \mathrm{~d}\end{array}$ & $\begin{array}{l}\text { Nitenpyram exposure affected the DNA } \\
\text { damage and antioxidant enzymes } \\
\text { activity in the zebrafish livers }\end{array}$ & [93] \\
\hline $\begin{array}{l}\text { Cyprodinil, } \\
\text { Thiacloprid }\end{array}$ & Danio rerio & $\begin{array}{l}\text { CY } 0.31 \text { and } 0.155 \mathrm{ppm} \\
\text { TLC } 1.64 \text { and } 0.82 \mathrm{ppm} 21 \mathrm{~d}\end{array}$ & $\begin{array}{c}\text { Cyprodinil and thiacloprid were } \\
\text { identified as genotoxic agents damaging } \\
\text { DNA }\end{array}$ & [91] \\
\hline \multirow{4}{*}{$\begin{array}{c}\text { Phoxim, } \\
\text { Atrazine, } \\
\text { Butachlor } \\
\lambda \text {-cyhalothrin }\end{array}$} & \multirow{4}{*}{ Danio rerio } & $\mathrm{LC}_{50}-96 \mathrm{~h}(\mathrm{ppm})$ & \multirow{4}{*}{$\begin{array}{l}\text { Synergistic effect of pesticides in } \\
\text { mixtures observed }\end{array}$} & \multirow{4}{*}{ [94] } \\
\hline & & $0.0031-0.38$ & & \\
\hline & & $0.45-1.93$ & & \\
\hline & & $6.09-34.19$ & & \\
\hline Imidacloprid & $\begin{array}{l}\text { Danio rerio } \\
\text { Oryzias latipes }\end{array}$ & $\begin{array}{l}0.2 \text { to } 2000 \mathrm{ppb} \\
\text { D. rerio } 5 \mathrm{dpf} \\
\text { O. latipes } 14 \mathrm{dpf}\end{array}$ & $\begin{array}{l}\text { Imidacloprid exposure indicated } \\
\text { sub-lethal effects in both species; with } \\
\text { prominent impacts in medaka, e.g., } \\
\text { lesions, reduced growth being and } \\
\text { deformities }\end{array}$ & [95] \\
\hline Imidacloprid & $\begin{array}{l}\text { Danio rerio } \\
\text { Oryzias latipes }\end{array}$ & $\begin{array}{c}0,0.2,2,20,200 \text { and } 2000 \mathrm{ppb} \\
\text { D. rerio } 5 \mathrm{dpf} \\
\text { O. latipes } 13 \mathrm{dpf}\end{array}$ & $\begin{array}{c}\text { Remarkable difference observed in } \\
\text { organism morphology: with major } \\
\text { deformities in medaka, however, almost } \\
\text { none observed in zebrafish }\end{array}$ & [96] \\
\hline $\begin{array}{l}\text { Imidacloprid, } \\
\text { Nitenpyram }\end{array}$ & Gobiocypris rarus (brains) & $\begin{array}{l}0.1,0.5 \text { and } 2.0 \mathrm{ppm} \\
60 \mathrm{~d}\end{array}$ & $\begin{array}{l}\text { Nitenpyram and imidacloprid altered } \\
\text { the antioxidant genes expression levels } \\
\text { and induced oxidative stress in brains of } \\
\text { juvenile Chinese rare minnow }\end{array}$ & [98] \\
\hline \multirow{3}{*}{$\begin{array}{l}\text { Thiamethoxam, } \\
\text { Tebuconazole }\end{array}$} & \multirow{3}{*}{ Gobiocypris rarus } & $\mathrm{LC}_{50}-96 \mathrm{~h}(\mathrm{ppm})$ & \multirow{3}{*}{$\begin{array}{l}\text { Synergistic action and additive toxicity } \\
\text { were observed }\end{array}$} & \multirow{3}{*}{ [99] } \\
\hline & & 4.07 & & \\
\hline & & 351.9 & & \\
\hline
\end{tabular}


Table 2. Cont.

\begin{tabular}{|c|c|c|c|c|}
\hline Type of Neonicotinoid & Species & Concentration and Time & Biological Effects & Reference \\
\hline $\begin{array}{l}\text { Nitenpyram, } \\
\text { Imidacloprid, } \\
\text { Dinotefuran }\end{array}$ & Gobiocypris rarus & $0.1,0.5$, or $2.0 \mathrm{ppm} 60 \mathrm{~d}$ & $\begin{array}{l}\text { DNA damage and Oxidative stress was } \\
\text { depicted after nitenpyram and } \\
\text { imidacloprid exposure which cause } \\
\text { adverse effects on juvenile G. rarus liver } \\
\text { in dose-dependent manner }\end{array}$ & [109] \\
\hline $\begin{array}{l}\text { Nitenpyram, } \\
\text { Imidacloprid, } \\
\text { Dinotefuran }\end{array}$ & Gobiocypris rarus & $\begin{array}{l}0.1,0.5, \text { or } 2.0 \mathrm{ppm} \\
60 \text { days }\end{array}$ & $\begin{array}{l}\text { Imidacloprid can induce genotoxicity. } \\
\text { Chronic dinotefuran and imidacloprid } \\
\text { might significantly reduce the immune } \\
\text { system of juvenile G. rarus }\end{array}$ & [97] \\
\hline $\begin{array}{l}\text { Imidacloprid, } \\
\text { Thiamethoxam }\end{array}$ & $\begin{array}{l}\text { Perca flavescens } \\
\text { larvae }\end{array}$ & $\begin{array}{c}\text { Survival probability: } 0,8.33 \text {, and } 23.32 \mathrm{ppt} \\
\text { Protein in tissues: } 8.33 \text {, and } 23.32,132.28 \mathrm{ppt} \\
\text { AChE activity: } 8.33 \text {, and } 23.32,132.28 \mathrm{ppt} \\
\text { With and without UVR }\end{array}$ & $\begin{array}{l}\text { Imidacloprid demonstrated rise in AChE } \\
\text { activity and protein content. } \\
\text { Imidacloprid and UVR both factors } \\
\text { disturb signal transmission in the } \\
\text { nervous system of fish larvae and } \\
\text { reduction in lipid peroxidation }\end{array}$ & [100] \\
\hline Clothianidin & Oncorhynchus nerka & $\begin{array}{l}0.15,1.5,15 \text { and } 150 \mathrm{ppb} \\
4 \text { months }\end{array}$ & $\begin{array}{c}\text { Clothianidin at } 0.15 \mathrm{ppb} \text { raised } \\
17 \beta \text {-estradiol levels in O. nerka swim-up } \\
\text { fry, testosterone levels were not affected } \\
\text { Clothianidin }(150 \mathrm{ppb}) \text { decreased Liver } \\
\text { glucocorticoid gene expression to } O . \\
\text { nerka swim-up fry }\end{array}$ & [101] \\
\hline Imidacloprid & Australoheros facetus & $\begin{array}{l}100,300,2500 \mathrm{ppb} \\
24 \text { and } 48 \mathrm{~h}\end{array}$ & $\begin{array}{l}\text { Imidacloprid was found in all the tested } \\
\text { gut, gills, muscle and liver tissues }\end{array}$ & [102] \\
\hline \multirow{5}{*}{$\begin{array}{l}\text { Acetamiprid, } \\
\text { Lambda-cyhalothrin, } \\
\text { ACT-LCh, } \\
\text { ACER 35 EC }{ }^{\circledR}\end{array}$} & \multirow{5}{*}{ Clarias gariepinus } & $\mathrm{LC}_{50} 96 \mathrm{~h}(\mathrm{ppm})$ & \multirow{5}{*}{$\begin{array}{c}\text { Additive and antagonistic results were } \\
\text { observed with marked nervous system } \\
\text { damage }\end{array}$} & \multirow{5}{*}{ [103] } \\
\hline & & 0.00083 & & \\
\hline & & 265.7 & & \\
\hline & & ACT-LCh & & \\
\hline & & ACER $35 \mathrm{EC}^{\circledR}$ & & \\
\hline
\end{tabular}


Table 2. Cont

\begin{tabular}{|c|c|c|c|c|}
\hline Type of Neonicotinoid & Species & Concentration and Time & Biological Effects & Reference \\
\hline Imidacloprid & Prochilodus lineatus & $1.25,12.5,125$, and $1250 \mathrm{ppb} 120 \mathrm{~h}$ & $\begin{array}{l}\text { After IMI exposure liver and kidney } \\
\text { were observed to be most affected } \\
\text { organs, followed by the gills }\end{array}$ & [110] \\
\hline Thiacloprid & Cyprinus carpio & $4.5,45,225$, and $450 \mathrm{ppb}$ for 35 days & $\begin{array}{l}\text { Thiacloprid caused reduced growth and } \\
\text { delay in ontogenetic development of carp }\end{array}$ & [111] \\
\hline \multicolumn{5}{|c|}{ Frog } \\
\hline $\begin{array}{l}\text { Clothianidin, } \\
\text { Thiamethoxam }\end{array}$ & $\begin{array}{l}\text { Lithobates sylvaticus, } \\
\text { Lithobates pipiens }\end{array}$ & $\begin{array}{l}2.5 \text { and } 250 \mathrm{ppb} \\
2 \text { weeks }\end{array}$ & $\begin{array}{c}\text { Neonicotinoid exposure did not show } \\
\text { variation among controls and exposed } \\
\text { groups for any of the parameters } \\
\text { observed for either leopard or wood } \\
\text { frogs }\end{array}$ & [104] \\
\hline $\begin{array}{l}\text { Imidacloprid, } \\
\text { Thiamethoxam }\end{array}$ & Lithobates sylvaticus & $\begin{array}{l}1,10 \text {, and } 100 \mathrm{ppb} \\
6 \text { weeks }\end{array}$ & $\begin{array}{l}\text { Frog's ability was affected to respond to } \\
\text { predators, significantly augmenting their } \\
\text { vulnerability to predation }\end{array}$ & [107] \\
\hline Clothianidin & Rana pipiens & $\begin{array}{c}0,0.23,1,10 \text { and } 100 \mathrm{ppb} \\
8 \text { weeks }\end{array}$ & $\begin{array}{c}\text { Increase in stress response such as } \\
\text { oxidative stress and change in leukocyte } \\
\text { profile were observed }\end{array}$ & [106] \\
\hline $\begin{array}{l}\text { Acetamiprid, } \\
\text { Clothianidin, } \\
\text { Dinotefuran, } \\
\text { Imidacloprid }\end{array}$ & Silurana tropicalis & $\begin{array}{l}96 \mathrm{~h} \text { semi-static test } \\
0.1 \text { and } 1.0 \mathrm{ppm}\end{array}$ & $\begin{array}{l}\text { Amphibians were not directly affected } \\
\text { by insecticides alone through larval } \\
\text { stages at concentrations that are } \\
\text { probably present in paddy water }\end{array}$ & [108] \\
\hline
\end{tabular}

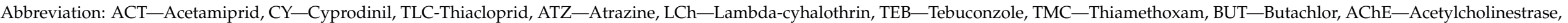

UVR-Ultraviolet radiation. 


\section{Future Direction of Work}

The "systemic insecticides" neonicotinoids, is a rapidly growing class of insecticides used worldwide with registered agricultural usage in field crops among countries worldwide. Studies on these insecticides indicate that they are persistent in the environment and display run-off potential and high leaching, and could be toxic to a wide range of aquatic organisms. The impact of neonicotinoids can be observed either directly or through indirect means of dis-balancing the food chain by blocking food or nutrient supply. A prominent variation amongst $\mathrm{EC}_{50}$ calculated amongst taxa and neonicotinoids was observed in accumulated data in this review, while sub-lethal values obtained occurred at concentration orders below the values which can cause lethality. These chemicals can also exert harmful effects on the growth, survival, behavior, and mobility of aquatic species at concentrations at or below $1 \mathrm{ppb}$ in acute exposure and at $0.1 \mathrm{ppb}$ during chronic exposure.

There is a need to understand the threshold of neonicotinoids in water to avert their persisting effects in aquatic communities. In this review, studies based on adverse effects of neonicotinoids on aquatic vertebrates are less in comparison to aquatic invertebrates were noted, which limits the understanding of the working effects and mechanisms of neonicotinoids. Aquatic vertebrate feeds on aquatic invertebrates. Thus, it is critical to gain knowledge on the effects of neonicotinoids on vertebrate models to set protective guidelines or policies for the ecological web.

Also in consideration, the potential uses of these insecticides, their additive or synergistic effects on organisms, their responses under a different set of environmental conditions such as salinity, $\mathrm{pH}$, temperature, etc. should be carefully analyzed and reported when formulating useful, regulatory guidelines. The dearth of research and problem in determining causing agent/factor of indirect effects is more important than direct toxicity effects on model organisms under observations. By far imidacloprid has been the most widely studied neonicotinoid owing to its extensive presence in the marketplace and agricultural usage. Variations in sensitivity and response between aquatic species demonstrated changes in several orders of magnitude of imidacloprid. Other classes of neonicotinoids were observed to exhibit analogous/synergistic modes of action and comparable toxicities. However, to confirm these reports, limited comparative studies are found in the literature. The current data depicts risk assessment for neonicotinoids to consider probability from indirect and direct effects to model organisms. Therefore, it is important to address information gaps to further understand the regulatory mechanisms of neonicotinoids, which ultimately allows the formulation of well-versed guidelines and registration grades to preserve the aquatic ecosystem.

Author Contributions: Conceptualization, N.M., K.H.-C.C. and C.-D.H.; validation, J.-C.H. and H.-T.L.; investigation, B.U., M.J.M.R. and A.P.G.M.; resources, T.-R.G.; writing-original draft preparation, N.M., K.H.-C.C., A.P.G.M., T.-R.G. and C.-D.H.; visualization, C.-D.H.; supervision and funding acquisition, T.-R.G. and C.-D.H. All authors have read and agreed to the published version of the manuscript.

Funding: This study was funded by grants sponsored by the Ministry of Science Technology 1082313-B-033 -001 -MY3 to C.-D.H., and MOST108-2221-E033-017-MY3 to T.-R.G.

Institutional Review Board Statement: Not applicable.

Informed Consent Statement: Not applicable.

Data Availability Statement: The data presented in this study are available on request from the corresponding author.

Acknowledgments: We appreciate two anonymous reviewers for providing valuable comments to enhance the quality of the paper. We appreciate Petrus Siregar to do paper editing.

Conflicts of Interest: The authors declare no conflict of interest. 


\section{References}

1. Richardson, J.R.; Fitsanakis, V.; Westerink, R.H.; Kanthasamy, A.G. Neurotoxicity of pesticides. Acta Neuropathol. 2019, 138, 343-362. [CrossRef]

2. Borsuah, J.F.; Messer, T.L.; Snow, D.D.; Comfort, S.D.; Mittelstet, A.R. Literature review: Global neonicotinoid insecticide occurrence in aquatic environments. Water 2020, 12, 3388. [CrossRef]

3. Mahai, G.; Wan, Y.; Xia, W.; Yang, S.; He, Z.; Xu, S. Neonicotinoid insecticides in surface water from the central Yangtze River, china. Chemosphere 2019, 229, 452-460. [CrossRef]

4. Hladik, M.L.; Kolpin, D.W.; Kuivila, K.M. Widespread occurrence of neonicotinoid insecticides in streams in a high corn and soybean producing region, USA. Environ. Pollut. 2014, 193, 189-196. [CrossRef]

5. Goulson, D. An overview of the environmental risks posed by neonicotinoid insecticides. J. Appl. Ecol. 2013, 50, 977-987. [CrossRef]

6. Jeschke, P.; Nauen, R.; Schindler, M.; Elbert, A. Overview of the status and global strategy for neonicotinoids. J. Agric. Food Chem. 2011, 59, 2897-2908. [CrossRef] [PubMed]

7. Nauen, R.; Denholm, I. Resistance of insect pests to neonicotinoid insecticides: Current status and future prospects. Arch. Insect Biochem. Physiol. Publ. Collab. Entomol. Soc. Am. 2005, 58, 200-215. [CrossRef] [PubMed]

8. Vogel, G. Where have all the insects gone? In Science; American Association for the Advancement of Science: Washington, DC, USA, 2017.

9. Sánchez-Bayo, F.; Wyckhuys, K.A. Worldwide decline of the entomofauna: A review of its drivers. Biol. Conserv. 2019, 232, 8-27. [CrossRef]

10. Feng, J.; Liu, R.; Chen, P.; Yuan, S.; Zhao, D.; Zhang, J.; Zheng, Z. Degradation of aqueous 3, 4-dichloroaniline by a novel dielectric barrier discharge plasma reactor. Environ. Sci. Pollut. Res. 2015, 22, 4447-4459. [CrossRef] [PubMed]

11. Bonmatin, J.-M.; Giorio, C.; Sánchez-Bayo, F.; van Lexmond, M.B. An Update of the Worldwide Integrated Assessment (WIA) on Systemic Insecticides; Springer: New York, NY, USA, 2021.

12. Desneux, N.; Decourtye, A.; Delpuech, J.-M. The sublethal effects of pesticides on beneficial arthropods. Annu. Rev. Entomol. 2007, 52, 81-106. [CrossRef]

13. Sánchez-Bayo, F.; Goulson, D.; Pennacchio, F.; Nazzi, F.; Goka, K.; Desneux, N. Are bee diseases linked to pesticides?-A brief review. Environ. Int. 2016, 89, 7-11. [CrossRef]

14. Cimino, A.M.; Boyles, A.L.; Thayer, K.A.; Perry, M.J. Effects of neonicotinoid pesticide exposure on human health: A systematic review. Environ. Health Perspect. 2017, 125, 155-162. [CrossRef]

15. Pagano, M.; Stara, A.; Aliko, V.; Faggio, C. Impact of neonicotinoids to aquatic invertebrates-In vitro studies on mytilus galloprovincialis: A review. J. Mar. Sci. Eng. 2020, 8, 801. [CrossRef]

16. Bonmatin, J.-M.; Noome, D.A.; Moreno, H.; Mitchell, E.A.; Glauser, G.; Soumana, O.S.; van Lexmond, M.B.; Sánchez-Bayo, F. A survey and risk assessment of neonicotinoids in water, soil and sediments of belize. Environ. Pollut. 2019, 249, 949-958. [CrossRef]

17. Bonmatin, J.-M.; Giorio, C.; Girolami, V.; Goulson, D.; Kreutzweiser, D.; Krupke, C.; Liess, M.; Long, E.; Marzaro, M.; Mitchell, E.A. Environmental fate and exposure; neonicotinoids and fipronil. Environ. Sci. Pollut. Res. 2015, 22, 35-67. [CrossRef] [PubMed]

18. Raby, M.; Nowierski, M.; Perlov, D.; Zhao, X.; Hao, C.; Poirier, D.G.; Sibley, P.K. Acute toxicity of 6 neonicotinoid insecticides to freshwater invertebrates. Environ. Toxicol. Chem. 2018, 37, 1430-1445. [CrossRef] [PubMed]

19. Basley, K.; Goulson, D. Neonicotinoids thiamethoxam and clothianidin adversely affect the colonisation of invertebrate populations in aquatic microcosms. Environ. Sci. Pollut. Res. 2018, 25, 9593-9599. [CrossRef]

20. Pisa, L.W.; Amaral-Rogers, V.; Belzunces, L.P.; Bonmatin, J.-M.; Downs, C.A.; Goulson, D.; Kreutzweiser, D.P.; Krupke, C.; Liess, M.; McField, M. Effects of neonicotinoids and fipronil on non-target invertebrates. Environ. Sci. Pollut. Res. 2015, 22, 68-102. [CrossRef]

21. Starner, K.; Goh, K.S. Detections of the neonicotinoid insecticide imidacloprid in surface waters of three agricultural regions of california, USA, 2010-2011. Bull. Environ. Contam. Toxicol. 2012, 88, 316-321. [CrossRef] [PubMed]

22. Jeschke, P.; Nauen, R. Neonicotinoids-From zero to hero in insecticide chemistry. Pest Manag. Sci. Former. Pestic. Sci. 2008, 64, 1084-1098. [CrossRef]

23. Tomizawa, M.; Casida, J.E. Neonicotinoid Insecticides: Highlights of a Symposium on Strategic Molecular Designs; ACS Publications: Washington, DC, USA, 2011.

24. Casida, J.E.; Durkin, K.A. Neuroactive insecticides: Targets, selectivity, resistance, and secondary effects. Annu. Rev. Entomol. 2013, 58, 99-117. [CrossRef]

25. Gibbons, D.; Morrissey, C.; Mineau, P. A review of the direct and indirect effects of neonicotinoids and fipronil on vertebrate wildlife. Environ. Sci. Pollut. Res. 2015, 22, 103-118. [CrossRef] [PubMed]

26. Ma, X.; Li, H.; Xiong, J.; Mehler, W.T.; You, J. Developmental toxicity of a neonicotinoid insecticide, acetamiprid to zebrafish embryos. J. Agric. Food Chem. 2019, 67, 2429-2436. [CrossRef] [PubMed]

27. Yamamuro, M.; Komuro, T.; Kamiya, H.; Kato, T.; Hasegawa, H.; Kameda, Y. Neonicotinoids disrupt aquatic food webs and decrease fishery yields. Science 2019, 366, 620-623. [CrossRef]

28. Nauen, R.; Ebbinghaus-Kintscher, U.; Elbert, A.; Jeschke, P.; Tietjen, K. Acetylcholine receptors as sites for developing neonicotinoid insecticides. In Biochemical Sites of Insecticide Action and Resistance; Springer: New York, NY, USA, 2001; pp. 77-105. 
29. Tomizawa, M.; Yamamoto, I. Structure-activity relationships of nicotinoids and imidacloprid analogs. J. Pestic. Sci. 1993, 18, 91-98. [CrossRef]

30. Tomizawa, M.; Casida, J.E. Selective toxicity of neonicotinoids attributable to specificity of insect and mammalian nicotinic receptors. Annu. Rev. Entomol. 2003, 48, 339-364. [CrossRef]

31. Jeschke, P.; Nauen, R. Neonicotinoid Insecticides; Elsevier: Amsterdam, The Netherlands, 2005.

32. Wexler, P.; Anderson, B.D.; Gad, S.C.; Hakkinen, P.B.; Kamrin, M.; De Peyster, A.; Locey, B.; Pope, C.; Mehendale, H.M.; Shugart, L.R. Encyclopedia of Toxicology; Academic Press: Cambridge, MA, USA, 2005; Volume 1.

33. Seifert, J. Neonicotinoids; Elsevier: Amsterdam, The Netherlands, 2014.

34. Crossthwaite, A.J.; Bigot, A.; Camblin, P.; Goodchild, J.; Lind, R.J.; Slater, R.; Maienfisch, P. The invertebrate pharmacology of insecticides acting at nicotinic acetylcholine receptors. J. Pestic. Sci. 2017, 42, D17-D19. [CrossRef]

35. Beck, M.E.; Gutbrod, O.; Matthiesen, S. Insight into the binding mode of agonists of the nicotinic acetylcholine receptor from calculated electron densities. ChemPhysChem 2015, 16, 2760. [CrossRef]

36. Teralı, K. An evaluation of neonicotinoids' potential to inhibit human cholinesterases: Protein-ligand docking and interaction profiling studies. J. Mol. Graph. Model. 2018, 84, 54-63. [CrossRef] [PubMed]

37. Wu, Z.-S.; Cheng, H.; Jiang, Y.; Melcher, K.; Xu, H.E. Ion channels gated by acetylcholine and serotonin: Structures, biology, and drug discovery. Acta Pharmacol. Sin. 2015, 36, 895-907. [CrossRef] [PubMed]

38. Millar, N.S.; Denholm, I. Nicotinic acetylcholine receptors: Targets for commercially important insecticides. Invertebr. Neurosci. 2007, 7, 53-66. [CrossRef]

39. Houchat, J.-N.; Cartereau, A.; Le Mauff, A.; Taillebois, E.; Thany, S.H. An overview on the effect of neonicotinoid insecticides on mammalian cholinergic functions through the activation of neuronal nicotinic acetylcholine receptors. Int. J. Environ. Res. Public Health 2020, 17, 3222. [CrossRef]

40. Ihara, M.; Okajima, T.; Yamashita, A.; Oda, T.; Asano, T.; Matsui, M.; Sattelle, D.B.; Matsuda, K. Studies on an acetylcholine binding protein identify a basic residue in loop $\mathrm{g}$ on the $\beta 1$ strand as a new structural determinant of neonicotinoid actions. Mol. Pharmacol. 2014, 86, 736-746. [CrossRef]

41. Shimomura, M.; Yokota, M.; Ihara, M.; Akamatsu, M.; Sattelle, D.B.; Matsuda, K. Role in the selectivity of neonicotinoids of insect-specific basic residues in loop d of the nicotinic acetylcholine receptor agonist binding site. Mol. Pharmacol. 2006, 70, 1255-1263. [CrossRef] [PubMed]

42. Siregar, P.; Suryanto, M.E.; Chen, K.H.-C.; Huang, J.-C.; Chen, H.-M.; Kurnia, K.A.; Santoso, F.; Hussain, A.; Ngoc Hieu, B.T.; Saputra, F. Exploiting the freshwater shrimp neocaridina denticulata as aquatic invertebrate model to evaluate nontargeted pesticide induced toxicity by investigating physiologic and biochemical parameters. Antioxidants 2021, 10, 391. [CrossRef]

43. Sánchez-Bayo, F.; Tennekes, H.A. Time-cumulative toxicity of neonicotinoids: Experimental evidence and implications for environmental risk assessments. Int. J. Environ. Res. Public Health 2020, 17, 1629. [CrossRef]

44. Rittschof, D.; McClellan-Green, P. Molluscs as multidisciplinary models in environment toxicology. Mar. Pollut. Bull. 2005, 50, 369-373. [CrossRef] [PubMed]

45. Schuler, T.; Denholm, I.; Jouanin, L.; Clark, S.; Clark, A.; Poppy, G. Population-scale laboratory studies of the effect of transgenic plants on nontarget insects. Mol. Ecol. 2001, 10, 1845-1853. [CrossRef] [PubMed]

46. Sánchez-Bayo, F.; Goka, K. Influence of light in acute toxicity bioassays of imidacloprid and zinc pyrithione to zooplankton crustaceans. Aquat. Toxicol. 2006, 78, 262-271. [CrossRef]

47. Hayasaka, D.; Suzuki, K.; Nomura, T.; Nishiyama, M.; Nagai, T.; Sánchez-Bayo, F.; Goka, K. Comparison of acute toxicity of two neonicotinoid insecticides, imidacloprid and clothianidin, to five cladoceran species. J. Pestic. Sci. 2013, 38, 44-47. [CrossRef]

48. Zein, M.A.; McElmurry, S.P.; Kashian, D.R.; Savolainen, P.T.; Pitts, D.K. Optical bioassay for measuring sublethal toxicity of insecticides in daphnia pulex. Environ. Toxicol. Chem. 2014, 33, 144-151. [CrossRef]

49. Raby, M.; Zhao, X.; Hao, C.; Poirier, D.G.; Sibley, P.K. Chronic effects of an environmentally-relevant, short-term neonicotinoid insecticide pulse on four aquatic invertebrates. Sci. Total Environ. 2018, 639, 1543-1552. [CrossRef]

50. Barbee, G.C.; Stout, M.J. Comparative acute toxicity of neonicotinoid and pyrethroid insecticides to non-target crayfish (procambarus clarkii) associated with rice-crayfish crop rotations. Pest Manag. Sci. Former. Pestic. Sci. 2009, 65, 1250-1256. [CrossRef] [PubMed]

51. Van den Brink, P.J.; Van Smeden, J.M.; Bekele, R.S.; Dierick, W.; De Gelder, D.M.; Noteboom, M.; Roessink, I. Acute and chronic toxicity of neonicotinoids to nymphs of a mayfly species and some notes on seasonal differences. Environ. Toxicol. Chem. 2016, 35, 128-133. [CrossRef]

52. Macaulay, S.J.; Hageman, K.J.; Alumbaugh, R.E.; Lyons, S.M.; Piggott, J.J.; Matthaei, C.D. Chronic toxicities of neonicotinoids to nymphs of the common new zealand mayfly deleatidium spp. Environ. Toxicol. Chem. 2019, 38, 2459-2471. [CrossRef] [PubMed]

53. Roessink, I.; Merga, L.B.; Zweers, H.J.; Van den Brink, P.J. The neonicotinoid imidacloprid shows high chronic toxicity to mayfly nymphs. Environ. Toxicol. Chem. 2013, 32, 1096-1100. [CrossRef]

54. Finnegan, M.C.; Baxter, L.R.; Maul, J.D.; Hanson, M.L.; Hoekstra, P.F. Comprehensive characterization of the acute and chronic toxicity of the neonicotinoid insecticide thiamethoxam to a suite of aquatic primary producers, invertebrates, and fish. Environ. Toxicol. Chem. 2017, 36, 2838-2848. [CrossRef] [PubMed] 
55. Rico, A.; Arenas-Sánchez, A.; Pasqualini, J.; García-Astillero, A.; Cherta, L.; Nozal, L.; Vighi, M. Effects of imidacloprid and a neonicotinoid mixture on aquatic invertebrate communities under mediterranean conditions. Aquat. Toxicol. 2018, 204, 130-143. [CrossRef]

56. Camp, A.; Buchwalter, D. Can't take the heat: Temperature-enhanced toxicity in the mayfly isonychia bicolor exposed to the neonicotinoid insecticide imidacloprid. Aquat. Toxicol. 2016, 178, 49-57. [CrossRef]

57. Macaulay, S.J.; Buchwalter, D.B.; Matthaei, C.D. Water temperature interacts with the insecticide imidacloprid to alter acute lethal and sublethal toxicity to mayfly larvae. N. Z. J. Mar. Freshw. Res. 2020, 54, 115-130. [CrossRef]

58. Macaulay, S.J.; Hageman, K.J.; Piggott, J.J.; Matthaei, C.D. Imidacloprid dominates the combined toxicities of neonicotinoid mixtures to stream mayfly nymphs. Sci. Total Environ. 2021, 761, 143263. [CrossRef]

59. Bartlett, A.J.; Hedges, A.M.; Intini, K.D.; Brown, L.R.; Maisonneuve, F.J.; Robinson, S.A.; Gillis, P.L.; de Solla, S.R. Acute and chronic toxicity of neonicotinoid and butenolide insecticides to the freshwater amphipod, hyalella azteca. Ecotoxicol. Environ. Saf. 2019, 175, 215-223. [CrossRef] [PubMed]

60. Bartlett, A.J.; Hedges, A.M.; Intini, K.D.; Brown, L.R.; Maisonneuve, F.J.; Robinson, S.A.; Gillis, P.L.; de Solla, S.R. Lethal and sublethal toxicity of neonicotinoid and butenolide insecticides to the mayfly, hexagenia spp. Environ. Pollut. 2018, 238, 63-75. [CrossRef] [PubMed]

61. Chandran, N.N.; Fojtova, D.; Blahova, L.; Rozmankova, E.; Blaha, L. Acute and (sub) chronic toxicity of the neonicotinoid imidacloprid on chironomus riparius. Chemosphere 2018, 209, 568-577. [CrossRef] [PubMed]

62. Wei, F.; Wang, D.; Li, H.; Xia, P.; Ran, Y.; You, J. Toxicogenomics provides insights to toxicity pathways of neonicotinoids to aquatic insect, chironomus dilutus. Environ. Pollut. 2020, 260, 114011. [CrossRef] [PubMed]

63. Maloney, E.; Liber, K.; Headley, J.; Peru, K.; Morrissey, C. Neonicotinoid insecticide mixtures: Evaluation of laboratory-based toxicity predictions under semi-controlled field conditions. Environ. Pollut. 2018, 243, 1727-1739. [CrossRef] [PubMed]

64. Cavallaro, M.C.; Morrissey, C.A.; Headley, J.V.; Peru, K.M.; Liber, K. Comparative chronic toxicity of imidacloprid, clothianidin, and thiamethoxam to chironomus dilutus and estimation of toxic equivalency factors. Environ. Toxicol. Chem. 2017, 36, 372-382. [CrossRef]

65. Barmentlo, S.H.; Vriend, L.M.; van Grunsven, R.H.; Vijver, M.G. Environmental levels of neonicotinoids reduce prey consumption, mobility and emergence of the damselfly ischnura elegans. J. Appl. Ecol. 2019, 56, 2034-2044. [CrossRef]

66. Raby, M.; Zhao, X.; Hao, C.; Poirier, D.G.; Sibley, P.K. Relative chronic sensitivity of neonicotinoid insecticides to ceriodaphnia dubia and daphnia magna. Ecotoxicol. Environ. Saf. 2018, 163, 238-244. [CrossRef]

67. Prosser, R.; De Solla, S.; Holman, E.; Osborne, R.; Robinson, S.; Bartlett, A.; Maisonneuve, F.; Gillis, P. Sensitivity of the early-life stages of freshwater mollusks to neonicotinoid and butenolide insecticides. Environ. Pollut. 2016, 218, 428-435.

68. Maloney, E.; Taillebois, E.; Gilles, N.; Morrissey, C.; Liber, K.; Servent, D.; Thany, S. Binding properties to nicotinic acetylcholine receptors can explain differential toxicity of neonicotinoid insecticides in chironomidae. Aquat. Toxicol. 2021, $230,105701$. [CrossRef]

69. Ewere, E.E.; Reichelt-Brushett, A.; Benkendorff, K. The neonicotinoid insecticide imidacloprid, but not salinity, impacts the immune system of sydney rock oyster, saccostrea glomerata. Sci. Total Environ. 2020, 742, 140538. [CrossRef]

70. Butcherine, P.; Kelaher, B.P.; Taylor, M.D.; Lawson, C.; Benkendorff, K. Acute toxicity, accumulation and sublethal effects of four neonicotinoids on juvenile black tiger shrimp (Penaeus monodon). Chemosphere 2021, 275, 129918. [CrossRef]

71. Butcherine, P.; Kelaher, B.P.; Taylor, M.D.; Barkla, B.J.; Benkendorff, K. Impact of imidacloprid on the nutritional quality of adult black tiger shrimp (penaeus monodon). Ecotoxicol. Environ. Saf. 2020, 198, 110682. [CrossRef]

72. Hook, S.E.; Doan, H.; Gonzago, D.; Musson, D.; Du, J.; Kookana, R.; Sellars, M.J.; Kumar, A. The impacts of modern-use pesticides on shrimp aquaculture: An assessment for north eastern australia. Ecotoxicol. Environ. Saf. 2018, 148, 770-780. [CrossRef]

73. Bownik, A.; Pawłocik, M.; Sokołowska, N. Effects of neonicotinoid insecticide acetamiprid on swimming velocity, heart rate and thoracic limb movement of daphnia magna. Pol. J. Nat. Sci. 2017, 32, 481-493.

74. Takács, E.; Klátyik, S.; Mörtl, M.; Rácz, G.; Kovács, K.; Darvas, B.; Székács, A. Effects of neonicotinoid insecticide formulations and their components on daphnia magna-the role of active ingredients and co-formulants. Int. J. Environ. Anal. Chem. 2017, 97, 885-900. [CrossRef]

75. Vehovszky, Á.; Farkas, A.; Csikós, V.; Székács, A.; Mörtl, M.; Győri, J. Neonicotinoid insecticides are potential substrates of the multixenobiotic resistance (mxr) mechanism in the non-target invertebrate, dreissena sp. Aquat. Toxicol. 2018, 205, 148-155. [CrossRef]

76. Stara, A.; Bellinvia, R.; Velisek, J.; Strouhova, A.; Kouba, A.; Faggio, C. Acute exposure of common yabby (cherax destructor) to the neonicotinoid pesticide. Sci. Total Environ. 2019, 665, 718-723. [CrossRef]

77. Berghiche, H.; Touati, K.; Chouahda, S.; Soltani, N. Impact of the neonicotinoid insecticide, actara ${ }^{\circledR}$, on the shrimp palaemon adspersus: Biomarkers measurement. In Euro-Mediterranean Conference for Environmental Integration; Springer: Cham, Switzerland, 2017; pp. 533-534.

78. Al-Badran, A.A.; Fujiwara, M.; Mora, M.A. Effects of insecticides, fipronil and imidacloprid, on the growth, survival, and behavior of brown shrimp farfantepenaeus aztecus. PLoS ONE 2019, 14, e0223641. [CrossRef] 
79. Omar, H.; Samir, H.; Khalil, M.S.; Ghorab, M.A.; Zwiernik, M.J. Acute Water Column Effects Concentrations (lc50, lc90) for Three Commonly Used Insecticides, Two Neonicotinoids (Acetamiprid and Imidacloprid), and a Recently Registered Phenylpyrazole (Fipronil), Exposed to Common Commercially Cultured Shrimp (Marsupenaeus japonicus); Michigan State University: East Lansing, MI, USA, 2016.

80. Stara, A.; Pagano, M.; Capillo, G.; Fabrello, J.; Sandova, M.; Vazzana, I.; Zuskova, E.; Velisek, J.; Matozzo, V.; Faggio, C. Assessing the effects of neonicotinoid insecticide on the bivalve mollusc mytilus galloprovincialis. Sci. Total Environ. 2020, 700, 134914 [CrossRef]

81. Vehovszky, Á.; Farkas, A.; Ács, A.; Stoliar, O.; Székács, A.; Mörtl, M.; Győri, J. Neonicotinoid insecticides inhibit cholinergic neurotransmission in a molluscan (Lymnaea stagnalis) nervous system. Aquat. Toxicol. 2015, 167, 172-179. [CrossRef]

82. Contardo-Jara, V.; Gessner, M.O. Uptake and physiological effects of the neonicotinoid imidacloprid and its commercial formulation confidor ${ }^{\circledR}$ in a widespread freshwater oligochaete. Environ. Pollut. 2020, 264, 114793. [CrossRef]

83. Hano, T.; Ito, K.; Ohkubo, N.; Ito, M.; Watanabe, A.; Sakaji, H. Involvement of oxygenase confers higher resistance to neonicotinoid insecticides in estuarine resident sand shrimp crangon uritai than in kuruma prawn penaeus japonicus and mysid americamysis bahia. Fish. Sci. 2020, 86, 1079-1086. [CrossRef]

84. De Esch, C.; Slieker, R.; Wolterbeek, A.; Woutersen, R.; de Groot, D. Zebrafish as potential model for developmental neurotoxicity testing: A mini review. Neurotoxicol. Teratol. 2012, 34, 545-553. [CrossRef]

85. Aleström, P.; Holter, J.L.; Nourizadeh-Lillabadi, R. Zebrafish in functional genomics and aquatic biomedicine. Trends Biotechnol. 2006, 24, 15-21. [CrossRef]

86. Padilla, S.; Cowden, J.; Hinton, D.E.; Yuen, B.; Law, S.; Kullman, S.W.; Johnson, R.; Hardman, R.C.; Flynn, K.; Au, D.W. Use of medaka in toxicity testing. Curr. Protoc. Toxicol. 2009, 39, 1-10. [CrossRef]

87. Luo, T.; Wang, X.; Jin, Y. Low concentrations of imidacloprid exposure induced gut toxicity in adult zebrafish (danio rerio). Comp. Biochem. Physiol. Part C Toxicol. Pharmacol. 2021, 241, 108972. [CrossRef] [PubMed]

88. Ge, W.; Yan, S.; Wang, J.; Zhu, L.; Chen, A.; Wang, J. Oxidative stress and DNA damage induced by imidacloprid in zebrafish (Denio rerio). J. Agric. Food Chem. 2015, 63, 1856-1862. [CrossRef] [PubMed]

89. Crosby, E.B.; Bailey, J.M.; Oliveri, A.N.; Levin, E.D. Neurobehavioral impairments caused by developmental imidacloprid exposure in zebrafish. Neurotoxicol. Teratol. 2015, 49, 81-90. [CrossRef]

90. Krishnan, A.; Clyburn, C.; Newcombe, P. Developmental effects of the pesticide imidacloprid on zebrafish body length and mortality. bioRxiv 2018, 395327. [CrossRef]

91. Toğay, V.A.; Türel, G.Y.; Çelik, D.A.; Özgöçmen, M.; Tülüceoğlu, E.E.; Şen, İ.; Ayvaz, Y. DNA damage effect of cyprodinil and thiacloprid in adult zebrafish gills. Environ. Sci. Pollut. Res. 2021, 28, 14482-14487. [CrossRef]

92. Yan, S.H.; Wang, J.H.; Zhu, L.S.; Chen, A.M.; Wang, J. Thiamethoxam induces oxidative stress and antioxidant response in zebrafish (Denio rerio) livers. Environ. Toxicol. 2016, 31, 2006-2015. [CrossRef]

93. Yan, S.; Wang, J.; Zhu, L.; Chen, A.; Wang, J. Toxic effects of nitenpyram on antioxidant enzyme system and DNA in zebrafish (Danio rerio) livers. Ecotoxicol. Environ. Saf. 2015, 122, 54-60. [CrossRef]

94. Wang, Y.; Lv, L.; Yu, Y.; Yang, G.; Xu, Z.; Wang, Q.; Cai, L. Single and joint toxic effects of five selected pesticides on the early life stages of zebrafish (Denio rerio). Chemosphere 2017, 170, 61-67. [CrossRef]

95. Vignet, C.; Cappello, T.; Fu, Q.; Lajoie, K.; De Marco, G.; Clérandeau, C.; Mottaz, H.; Maisano, M.; Hollender, J.; Schirmer, K. Imidacloprid induces adverse effects on fish early life stages that are more severe in japanese medaka (Oryzias latipes) than in zebrafish (Denio rerio). Chemosphere 2019, 225, 470-478. [CrossRef] [PubMed]

96. Vignet, C.; Lajoie, K.; Maisano, M.; Mottaz, H.; Clérandeau, C.; Cappello, T.; Schirmer, K.; Cachot, J. Response of Zebrafish and Japanese Medaka to Imidacloprid: A Comparative Study. In Proceedings of the SETAC Europe 27th Annual Meeting, Brussels, Belgium, 7-11 May 2017; Society of Environmental Toxicology and Chemistry Europe (SETAC Europe): Brussels, Belgium, 2017; p. 298.

97. Hong, X.; Zhao, X.; Tian, X.; Li, J.; Zha, J. Changes of hematological and biochemical parameters revealed genotoxicity and immunotoxicity of neonicotinoids on chinese rare minnows (Gobiocypris raru). Environ. Pollut. 2018, 233, 862-871. [CrossRef] [PubMed]

98. Tian, X.; Yang, W.; Wang, D.; Zhao, Y.; Yao, R.; Ma, L.; Ge, C.; Li, X.; Huang, Z.; He, L. Chronic brain toxicity response of juvenile chinese rare minnows (gobiocypris rarus) to the neonicotinoid insecticides imidacloprid and nitenpyram. Chemosphere 2018, 210, 1006-1012. [CrossRef]

99. Li, X.; Mao, L.; Zhang, Y.; Wang, X.; Wang, Y.; Wu, X. Joint toxic impacts of cadmium and three pesticides on embryonic development of rare minnow (Gobiocypris rarus). Environ. Sci. Pollut. Res. 2020, 27, 36596-36604. [CrossRef]

100. Paquet-Walsh, A.; Bertolo, A.; Landry, C.; Deschamps, L.; Boily, M. Interactive effects of neonicotinoids and natural ultraviolet radiation on yellow perch (Perca flavescens) larvae. Sci. Total Environ. 2019, 685, 690-701. [CrossRef]

101. Marlatt, V.L.; Leung, T.Y.G.; Calbick, S.; Metcalfe, C.; Kennedy, C. Sub-lethal effects of a neonicotinoid, clothianidin, on wild early life stage sockeye salmon (Oncorhynchus nerka). Aquat. Toxicol. 2019, 217, 105335. [CrossRef]

102. Iturburu, F.G.; Zömisch, M.; Panzeri, A.M.; Crupkin, A.C.; Contardo-Jara, V.; Pflugmacher, S.; Menone, M.L. Uptake, distribution in different tissues, and genotoxicity of imidacloprid in the freshwater fish australoheros facetus. Environ. Toxicol. Chem. 2017, 36, 699-708. [CrossRef] [PubMed] 
103. Houndji, M.A.; Imorou Toko, I.; Guedegba, L.; Yacouto, E.; Agbohessi, P.T.; Mandiki, S.N.; Scippo, M.-L.; Kestemont, P. Joint toxicity of two phytosanitary molecules, lambda-cyhalothrin and acetamiprid, on african catfish (Clarias gariepinus) juveniles. J. Environ. Sci. Health Part B 2020, 55, 669-676. [CrossRef]

104. Robinson, S.; Richardson, S.; Dalton, R.; Maisonneuve, F.; Bartlett, A.; de Solla, S.; Trudeau, V.; Waltho, N. Assessment of sublethal effects of neonicotinoid insecticides on the life-history traits of 2 frog species. Environ. Toxicol. Chem. 2019, 38, 1967-1977. [CrossRef]

105. Keller, P.G. Detection of Neonicotinoids in Northern Leopard Frog (Rana pipiens) Brains; University of South Dakota: Vermillion, SD, USA, 2021.

106. Robinson, S.A.; Chlebak, R.J.; Young, S.D.; Dalton, R.L.; Gavel, M.J.; Prosser, R.S.; Bartlett, A.J.; de Solla, S.R. Clothianidin alters leukocyte profiles and elevates measures of oxidative stress in tadpoles of the amphibian, rana pipiens. Environ. Pollut. 2021, 284, 117149. [CrossRef] [PubMed]

107. Lee-Jenkins, S.S.; Robinson, S.A. Effects of neonicotinoids on putative escape behavior of juvenile wood frogs (Lithobates sylvaticus) chronically exposed as tadpoles. Environ. Toxicol. Chem. 2018, 37, 3115-3123. [CrossRef] [PubMed]

108. Saka, M.; Tada, N. Acute and chronic toxicity tests of systemic insecticides, four neonicotinoids and fipronil, using the tadpoles of the western clawed frog silurana tropicalis. Chemosphere 2021, 270, 129418. [CrossRef]

109. Tian, X.; Hong, X.; Yan, S.; Li, X.; Wu, H.; Lin, A.; Yang, W. Neonicotinoids caused oxidative stress and DNA damage in juvenile chinese rare minnows (Gobiocypris rarus). Ecotoxicol. Environ. Saf. 2020, 197, 110566. [CrossRef]

110. Vieira, C.E.D.; Pérez, M.R.; Acayaba, R.D.A.; Raimundo, C.C.M.; dos Reis Martinez, C.B. DNA damage and oxidative stress induced by imidacloprid exposure in different tissues of the neotropical fish prochilodus lineatus. Chemosphere 2018, 195, 125-134. [CrossRef]

111. Velisek, J.; Stara, A. Effect of thiacloprid on early life stages of common carp (Cyprinus carpio). Chemosphere 2018, $194,481-487$. [CrossRef] 